Portland State University

PDXScholar

\title{
Water Supply, Demand, and Quality Indicators for Assessing the Spatial Distribution of Water Resource Vulnerability in the Columbia River Basin
}

\author{
Heejun Chang \\ Portland State University, changh@pdx.edu \\ II-Won Jung \\ Portland State University \\ Angela L. Strecker \\ Portland State University, angela.strecker@wwu.edu \\ Daniel Wise \\ U.S. Geological Survey \\ Martin Lafrenz \\ Portland State University \\ Follow this and additional works at: https://pdxscholar.library.pdx.edu/geog_fac \\ Part of the Hydrology Commons, and the Natural Resources Management and Policy Commons \\ seenext pagefor additional authors
}

\section{Citation Details}

Heejun Chang, II-Won Jung , Angela Strecker, Daniel Wise , Martin Lafrenz, Vivek Shandas , Hamid Moradkhani, Alan Yeakley, Yangdong Pan, Robert Bean, Gunnar Johnson \& Mike Psaris (2013) Water Supply, Demand, and Quality Indicators for Assessing the Spatial Distribution of Water Resource Vulnerability in the Columbia River Basin, Atmosphere-Ocean, 51:4, 339-356, DOI: 10.1080/ 07055900.2013 .777896

This Article is brought to you for free and open access. It has been accepted for inclusion in Geography Faculty Publications and Presentations by an authorized administrator of PDXScholar. Please contact us if we can make this document more accessible: pdxscholar@pdx.edu. 


\section{Authors}

Heejun Chang, II-Won Jung, Angela L. Strecker, Daniel Wise, Martin Lafrenz, Vivek Shandas, Hamid Moradkhani, J. Alan Yeakley, Yangdong Pan, Robert Allen Bean, Gunnar Johnson, and Mike Psaris 


\title{
Water Supply, Demand, and Quality Indicators for Assessing the Spatial Distribution of Water Resource Vulnerability in the Columbia River Basin
}

\author{
Heejun Chang ${ }^{1, *}$, Il-Won Jung ${ }^{1}$, Angela Strecker ${ }^{2}$, Daniel Wise ${ }^{3}$, Martin Lafrenz ${ }^{1}$, Vivek \\ Shandas ${ }^{4}$, Hamid Moradkhani ${ }^{5}$, Alan Yeakley ${ }^{2}$, Yangdong Pan $^{2}$, Robert Bean ${ }^{1}$, Gunnar Johnson ${ }^{2}$ \\ and Mike Psaris ${ }^{1}$ \\ ${ }^{I}$ Department of Geography, Portland State University, Portland, Oregon, USA \\ ${ }^{2}$ Department of Environmental Sciences and Management, Portland State University, Portland, \\ Oregon, USA \\ ${ }^{3}$ US Geological Survey, Oregon Water Science Center, Portland, Oregon, USA \\ ${ }^{4}$ School of Urban Studies and Planning, Portland State University, Portland, Oregon, USA \\ ${ }^{5}$ Department of Civil and Environmental Engineering, Portland State University, Portland, Oregon, \\ USA
}

\begin{abstract}
We investigated water resource vulnerability in the US portion of the Columbia River basin (CRB) using multiple indicators representing water supply, water demand, and water quality. Based on the US county scale, spatial analysis was conducted using various biophysical and socio-economic indicators that control water vulnerability. Water supply vulnerability and water demand vulnerability exhibited a similar spatial clustering of hotspots in areas where agricultural lands and variability of precipitation were high but dam storage capacity was low. The hotspots of water quality vulnerability were clustered around the main stem of the Columbia River where major population and agricultural centres are located. This multiple equal weight indicator approach confirmed that different drivers were associated with different vulnerability maps in the sub-basins of the CRB. Water quality variables are more important than water supply and water demand variables in the Willamette River basin, whereas water supply and demand variables are more important than water quality variables in the Upper Snake and Upper Columbia River basins. This result suggests that current water resources management and practices drive much of the vulnerability within the study area. The analysis suggests the need for increased coordination of water management across multiple levels of water governance to reduce water resource vulnerability in the CRB and a potentially different weighting scheme that explicitly takes into account the input of various water stakeholders.
\end{abstract}

RÉSUMÉ [Traduit par la rédaction] Nous étudions la vulnérabilité de la ressource en eau dans la partie étatsunienne du bassin du fleuve Columbia à l'aide d'indicateurs multiples représentant l'apport d'eau, la demande en eau et la qualité de l'eau. En nous basant sur l'échelle des comtés des États-Unis, nous avons fait une analyse spatiale à l'aide de divers indicateurs biophysiques et socio-économiques qui déterminent la vulnérabilité de l'eau. La vulnérabilité de l'apport d'eau et la vulnérabilité de la demande en eau ont exhibé un regroupement spatial similaire de points chauds dans les régions où il y avait beaucoup de terres agricoles et une grande variabilité dans les précipitations mais où il y avait une faible capacité de stockage par des barrages. Les points chauds de vulnérabilité de la qualité de l'eau étaient regroupés autour du bras principal du fleuve Columbia, où sont situés les principaux centres urbains et agricoles. Cette approche basée sur des indicateurs multiples de poids égaux a confirmé que différents facteurs étaient associés à différentes cartes de vulnérabilité dans les sous-bassins du bassin du fleuve Columbia. Les variables de qualité de l'eau sont plus importantes que les variables d'apport d'eau et de demande en eau dans le bassin de la rivière Willamette alors que les variables d'apport d'eau et de demande en eau sont plus importantes que les variables de qualité de l'eau dans les bassins des parties supérieures de la rivière Snake et du fleuve Columbia. Ce résultat donne à penser que la gestion et les pratiques courantes en matière de ressources en eau déterminent en grande partie la vulnérabilité à l'intérieur de la région étudiée. L'analyse semble indiquer le besoin d'une plus grande coordination de la gestion de l'eau entre plusieurs ordres de gouvernance de l'eau pour réduire la vulnérabilité de la ressource dans le bassin du fleuve Columbia et d'un schéma utilisant des poids différents qui prendrait explicitement en compte les commentaires de différents intéressés en matière d'eau.

${ }^{*}$ Corresponding author's email: changh@pdx.edu 


\section{0 / Heejun Chang et al.}

KEYWORDS water sustainability; vulnerability; water supply; water demand; water quality; multi-dimensional analysis; GIS; integrated water resource management

\section{Introduction}

\section{a Water Sustainability}

Water sustainability is one of the grand challenges facing society in the twenty-first century (Falkenmark, 2008). With ongoing land development driven by population growth and expected climate change, many regions of the world are facing the issues of water scarcity and water pollution, which threaten the long-term sustainability of water resources (Gleick, 2003). Climate, land use, and water management systems are considered the three major controls on hydrological regimes and water resources (Arnell, 1996). In this study, we assess water resource vulnerability in the US portion of the Columbia River basin (CRB) by using multiple indicators representative of water supply, water demand, and water quality to investigate spatial patterns of water resource vulnerability, the major controls on those patterns, and the utility of using an integrated approach to study this vulnerability.

Inputs of precipitation, temperature, evaporative demand (i.e., climate-related factors), vegetation and land cover characteristics (i.e., land-related factors), and spatial and temporal allocation of water resources (i.e., factors related to water management) are all important factors for assessing current water system vulnerability. Thus, they need to be considered in integrated water resource management under various environmental change scenarios (Metzger, Leemans, \& Schröter, 2005; Praskievicz \& Chang, 2011). Hydroclimatic modelling efforts currently indicate that water resource responses to climate change impacts are both global and local in scale. Altered precipitation patterns will reduce system yields because of streamflow changes, increased flooding, and changes in ecohydrologic factors particularly vegetation patterns (Moradkhani, Baird, \& Wherry, 2010; Najafi, Moradkhani, \& Jung, 2011).

Climate variability and change affect the water system through the hydrologic cycle by modifying water supply, water demand, and water quality. High climate variability often contributes to regional water resource vulnerability by increasing the frequency of extreme hydrologic events such as floods and droughts (Chang et al., 2010; Risley, Moradkhani, Hay, \& Markstrom, 2011; Sivakumar, 2011). A rise in air temperature is also associated with increasing irrigation and municipal water demand (Bougadis, Adamowski, \& Diduch, 2005; House-Peters \& Chang, 2011a), and increasing wind speed in combination with a temperature increase could accelerate crop water demand (Ali \& Adham, 2007). Water quality typically degrades after a prolonged dry period by substantially increasing nitrate concentrations (Saunders, Murphy, Clark, \& Lewis, 2004). Changes in the timing and amount of rainfall and temperature increases are associated with changes in seasonal water supply (Chang, Jung, Steele, \& Gannett, 2012). Additionally, changes in the intensity and frequency of rainfall and snowpack result in frequent regional droughts or floods (Chang \& Jung, 2010; Dettinger, 2011; Halmstad, Najafi, \& Moradkhani, 2012; Hamlet \& Lettenmaier, 2007; Jung \& Chang, 2011; Madadgar \& Moradkhani, 2012). Rising air temperatures are related to increased water temperature and reduced dissolved oxygen (Hester \& Doyle, 2011; Mantua, Tohver, \& Hamlet, 2010), thus affecting instream biogeochemical cycles and fish habitat (Brodersen et al., 2011). Changes in hydrological regimes driven by different rainfall characteristics affect sediment transport and deposition (Lane, Tayefi, Reid, Yu, \& Hardy 2007).

Land cover changes from forested lands to agricultural or impervious urban lands also affect various aspects of water resource vulnerability. First, increased impervious surface area resulting from urban and industrial development will make surface runoff flashier (i.e., increased peak flows) by lowering rates of soil-water infiltration and groundwater recharge. In a typical urban environment, wet-season flow becomes higher, while dry season flow becomes lower (Chang, 2007). Second, urban and agricultural land development will also increase water demand to sustain development (Franczyk \& Chang, 2009). It is well known that different spatial patterns of urban development are highly correlated to different water consumption patterns (House-Peters \& Chang, 2011b; Shandas \& Parandvash, 2010) and sensitivity to climate (Breyer, Chang, \& Prandvash, 2012).

Third, together with point source pollution, increases in storm runoff will deliver more urban and agricultural nonpoint source pollutants, such as thermal or nutrient pollution to water bodies, yet the concentration of constituents is likely to remain high during the low-flow season (Sonoda \& Yeakley, 2007). As a result, highly developed watersheds tend to have more impaired water quality and thus have increased vulnerability whereas less developed watersheds may be more resilient. Increased sediment loads in surface water have been repeatedly linked to land use change (Tang, Yang, Heping, \& Gao, 2011; Trimble \& Lund, 1982). In fact, the sediment budget approach to modelling sediment flux in a watershed is based largely on land use (Reid \& Dunne, 2003). Given the high degree of correlation between land use types and water quality (Snyder, Goetz, \& Wright, 2005), population pressure will increase water quality vulnerability and drive the need for innovative water quality management to be integrated within land use management.

The consequences of nutrient pollution could be significant, resulting in increased phytoplankton and benthic algal biomass, often in the form of toxic or bloom-forming species, decreased clarity and reduced esthetic value, taste and odour problems, oxygen depletion, and fish kills (Smith, 1998). In addition to environmental effects, increased nutrient concentrations can lead to human health effects, such as nitrogen toxicity, which has been linked to methemoglobinemia in infants, certain types of cancer, and birth defects (Carpenter 


\section{Water Resource Vulnerability in the Columbia River Basin / 341}

et al., 1998; Camargo \& Alonso, 2006), as well as health effects on livestock. Indirect effects of high nutrient loads on human health can result from increased production of toxic algae, including cyanobacteria (neurotoxins and hepatotoxins; Hitzfeld, Hoger, \& Dietrich, 2000), dinoflagellates in estuaries and coastal waters (paralytic and neurotoxic shellfish poisoning associated with red tides; Van Dolah, 2000; Van Dolah, Roelke, \& Greene, 2001), and marine diatoms (amnesic shellfish poisoning; Van Dolah, 2000).

\section{b Management of Waterways}

Water resource management could either exacerbate or ameliorate water resource vulnerability. Arguably, the current deteriorating state of waterways globally suggests that water management may need to better align scientific understanding with management of water resources, specifically in addressing the environmental and socio-economic stressors known to affect receiving waters (Falloon \& Betts, 2010). One mechanism that continues to stress water systems is the construction of dams to manage the timing and magnitude of water supply (Nilsson, Reidy, Dynesius, \& Revenga, 2005). While dams have, to some extent, achieved the goal of delivering a reliable water supply to downstream users, this management often comes at the expense of deteriorating ecological and biological integrity of freshwater ecosystems (Poff et al., 1997). Additionally, such dams have a limited lifespan; maintaining and repairing this infrastructure requires consideration of the integrated economic and environmental consequences throughout the watershed (Doyle et al., 2008). Current strategies for flood control and for reducing the vulnerability of the water supply mainly focus on measures to increase various thresholds (e.g., improved water storage and delivery infrastructure and dike building). Demand side management typically focuses on price control rather than integrating land use planning. Such strategies may not be sufficient to reduce vulnerability. Moreover, emerging evidence suggests a need for greater integration across known strategies to reduce vulnerability by focusing on better and more efficient water storage and delivery infrastructure in addition to demand management, water saving technology, and a decentralized, more flexible water supply (Polsky, Neff, \& Yarnal, 2007). Integrating demand and supply adds diversity to the options that society has available to face uncertain future developments and disturbances (Gober, Kirkwood, Balling, Ellis, \& Deitrick 2010).

Previous studies have identified a number of management techniques that can mitigate nutrient and sediment runoff into water bodies. Landscape features such as riparian vegetation and buffers, wetlands, conservation tillage, and retention ponds can reduce non-point sources of nutrients and convert nutrients to readily usable forms (Carpenter et al., 1998; Correll, Jordan, \& Weller, 1992; Shandas \& Alberti, 2009; Sharpley et al., 1994; Udawatta, Krstansky, Henderson, \& Garrett, 2002). Agricultural practices can be changed to manage nutrients better, such as reduced fertilizer application, nutrient application that matches crop and animal uptake rates, and best management practices that may significantly alter nitrogen and phosphorus transport (Carpenter et al., 1998; Makarewicz et al., 2009; Sharpley et al., 1994). In addition, some of the deleterious effects of urban runoff can be reduced by the creation of retention ponds and greenways, restoration of wetlands, reduction of impervious areas, and reduced industrial erosion (Carpenter et al., 1998).

Another reason for the continued degradation of waterways, and the one we explore in this study, is the lack of studies that integrate trends in water availability and quality with risks of drought or other supply-limiting conditions. Risks associated with declines in water availability or water quality are extensive in the literature; however, these studies often focus either on the physical changes to landscape and climate or on social stressors. An emerging area of research is the use of vulnerability indices that integrate multiple indicators to evaluate the extent of stress on a water system and the conditions that threaten the long-term sustainability of water resources.

\section{c Vulnerability Studies}

There have been several studies investigating water resource vulnerability worldwide. On a global scale, Vörösmarty, Green, Salisbury, and Lammers (2000), focusing on water supply, projected that rising water demand driven by population growth will outweigh climate change effects on global freshwater vulnerability in 2025. Similarly, Alcamo, Dronin, Endejan, Golubev, and Kirilenkoc (2007), using the Global Hydrology Model of WaterGAP under two Intergovernmental Panel on Climate Change (IPCC) greenhouse gas (GHG) emission scenarios, found that water stress is projected to increase in roughly two-thirds of the world's river basins, primarily driven by increases in domestic water use stemming from income growth. The authors found that population growth was a much less important factor than climate change although irrigated area was assumed to remain constant in the future. More recently, Doll and Zhang, (2010) assessed the impact of climate change on ecologically relevant river flow alteration and found that climate change impacts outweigh anthropogenic impacts such as the current levels of dams and water withdrawal. In a similar vein, Vörösmarty et al. (2010) quantified the major stressors of human water security and biodiversity threat at a global scale and identified that human water security threat and biodiversity threat are highly correlated in space, suggesting that a great part of global biodiversity is threatened by human water demand driven by population growth.

At a regional scale, several studies have been conducted to assess water resource vulnerability at the river basin scale. In the Canadian portion of the CRB, Cohen et al. (2006) examined water supply and demand in the semi-arid Okanagan basin, with consideration of future scenarios of moderate to severe climate change. Sullivan et al. (2003), for example, developed a water poverty index (WPI) to identify areas facing severe 


\section{2 / Heejun Chang et al.}

water stress in South Africa. The WPI was later applied in other countries, including Nepal (Manandhar, Pandey, \& Kazama, 2012). An extended version of the WPI is a climate vulnerability index that integrates social, biophysical, and economic information to assess human vulnerability to changes in water resources that result from climate change. Chaves and Alipaz (2007) developed a function to assess the water sustainability index of a medium-sized river basin in Brazil using four indicators: hydrology, environment, life, and policy. Hamouda, El-Din, and Moursy (2009) assessed water resource vulnerability in the Eastern Nile River basin using 31 indicators, including hydrophysical and socio-economic indicators. Jun, Chung, Sung, and Lee (2011) quantified water resources vulnerability indices under climate change scenarios in several sub-basins of the Han River basin in South Korea. They used four vulnerability indices, encompassing extreme hydrologic events (flood and drought damages), water quality, and watershed evaluation indices.

Although these earlier studies addressed some aspects of water resource vulnerability, they have not adequately addressed the suite of indicators that link water availability, demand, and quality, thus providing limited understanding of total water sustainability. Additionally, a global-scale analysis does not provide sufficient detail to understand the complex dynamics of coupled socio-ecological systems within a basin. No studies have yet examined regional water resource vulnerability in the CRB that simultaneously considers water supply, quality, and demand. Here we examine all three dimensions of water resource vulnerability in the US portion of the CRB, the largest river basin in the Pacific Northwest, at the scale of the county (i.e., a politically defined area of human governance between city and state levels in the United States). We were limited to the US portion of the basin because insufficient biophysical and social data were available on a consistent scale in the Canadian portion of the basin (i.e., no comparable countylevel data were available). Our research seeks to answer the following questions.

(i) What are the spatial patterns of water resource vulnerability in a large heterogeneous river basin?

(ii) What are the major controls of spatial water resource vulnerability?

(iii) What are the added values of studying water resource vulnerability using an integrated approach that encompasses water supply, demand, and quality?

\section{Data and methods}

\section{a Study Area}

Our study area comprised the US portion of the CRB (Fig. 1). The Columbia River, originating in the Rocky Mountains in British Columbia, is the largest river in the Pacific Northwest of the United States. The river is $2,000 \mathrm{~km}$ long and flows initially northwest, then turns south and runs to the border between Oregon and Washington before continuing west to the Pacific Ocean. It is the fourth largest river in the United

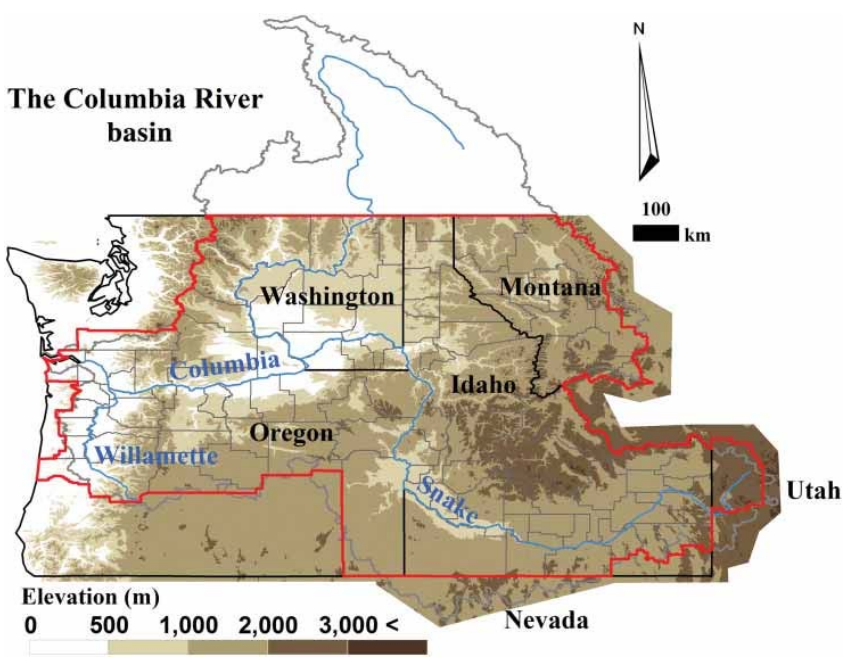

Fig. 1 Study area (outlined in red): five states and 104 counties, main rivers, and elevation.

States by volume and produces hydroelectricity from 14 hydroelectric dams on its main stem and many more on its major tributaries, such as the Willamette, Snake, and Spokane rivers. The basin's hydrology is complex, reflecting varying topography, elevation gradient, and proximity to the ocean. The basin drains portions of five US states and one Canadian province and has been an important resource for urban settlement and development, agriculture, transportation, recreation, fisheries, and hydropower generation. Because of the decline of most salmonid species in the basin during the twentieth century, the concept of environmental flow was introduced to adaptive river management (Arthington, Bunn, Poff, \& Naiman, 2006 and references therein). Environmental flows are those minimally required for fish migration and suitable habitat. Potential climate change, projected human population migration, production, and trade will likely decrease future water supply and increase summer water demand in the CRB. The upcoming renegotiation of the Columbia River compact between the United States and Canada is likely to complicate the basin-wide water issues further.

We used US counties as a unit of our analysis for the following reasons. First, the county is the smallest spatial scale for many socio-economic and water consumption data; hence, biophysical and socio-economic data can be analyzed together without the problem of ecological fallacy, a problem in statistics when small-scale characteristics are inferred from large-scale summary characteristics. Second, the county contains the most consistent and readily available datasets, allowing for systematic analysis across a large river basin. Third, the county scale is one of the smallest land and water resource planning and management units; therefore, the results of this study can be used for future planning and management purposes at this scale. As a result, counties may allow for relatively swift and tailored actions to address specific stressors. Because we are interested in assessing the current status of the vulnerability of water resources, we used 2005 as our 


\section{Water Resource Vulnerability in the Columbia River Basin / 343}

base year, the most recent year with available water use data. Accordingly, other biophysical and socio-economic data were selected from the time period around 2005.

\section{b Vulnerability Index: Overview}

In general, vulnerability is defined as a measure of the magnitude of a system's potential for failure (Maier, Lence, Tolson, \& Foschi, 2001). In a more elaborate definition, vulnerability is the exposure of a system to shocks, stresses, and disturbances, or the degree to which a system is susceptible to adverse effects (Leurs, 2005; McCarthy, 2001; Turner et al., 2003), or the degree to which a system is likely to experience harm from perturbation or stress (De Sherbinin, Schiller, \& Pulsipher, 2007). Vulnerability can be calculated using sophisticated approaches (e.g., Maier et al., 2001). In this study, however, to identify the current state of water vulnerability at the county scale of the CRB, we employed the indexbased approach of Sullivan (2011) that quantifies water vulnerability as an integration of several indicators representing the socio-economic and environmental status of the water resources system. We chose water supply, water demand, and water quality as our indicators on the basis of simplicity, data availability, repeatability, and consistency, including the range of the raw data (Table 1). These vulnerability indicators can be grouped into three classes representing hydroclimatologic, environmental, and socio-economic status of the study area. On the basis of the classes we assign equal weights to the indicators, assuming each indicator has the same level of importance. Although it is unlikely that most variables carry equal weight, determining the relative importance of all the variables is fraught with uncertainty; thus we consider this a conservative approach. All indicators were first normalized ranging from 0 to 100 using Eq. (1).

$$
p_{\text {norm }}=\frac{q-q_{\min }}{q_{\max }-q_{\min }} \times 100
$$

where $p_{\text {norm }}$ is the normalized indicator, $q$ is the indicator value, $q_{\min }$ and $q_{\max }$ are the minimum and maximum values of each indicator, respectively. Some normalized indicators such as mean annual runoff and total dam storage were rescaled using Eq. (2) so that higher values indicate higher stress on the water system.

$$
\operatorname{adj}_{p_{\text {norm }}}=100-p_{\text {norm }}
$$

where $\operatorname{adj}_{p_{\text {norm }}}$ is the rescaled value. The normalized indicators were aggregated into three vulnerability indices. The composite vulnerability indices were spatially normalized on a scale from 0 to 100 and were used to plot vulnerability maps.

\section{c Water Supply Vulnerability Index}

Water supply vulnerability is expressed as the combination of water resource availability, temporal variation in precipitation, extreme climatic circumstances, and land cover type for a specific region determined by the intrinsic natural variability and anthropogenic water systems (Sullivan, 2011; Sullivan et al., 2003). Low water availability and storage capacity, higher variation of water resources, and frequent extremes can induce high water stress. Also, highly developed areas (urban and irrigation land) reduce water supply capacity and natural water storage capacity in the ground. To quantify the water supply index at the county level of the CRB, we adopted

Table 1. Water vulnerability indicators, descriptions, and their sources.

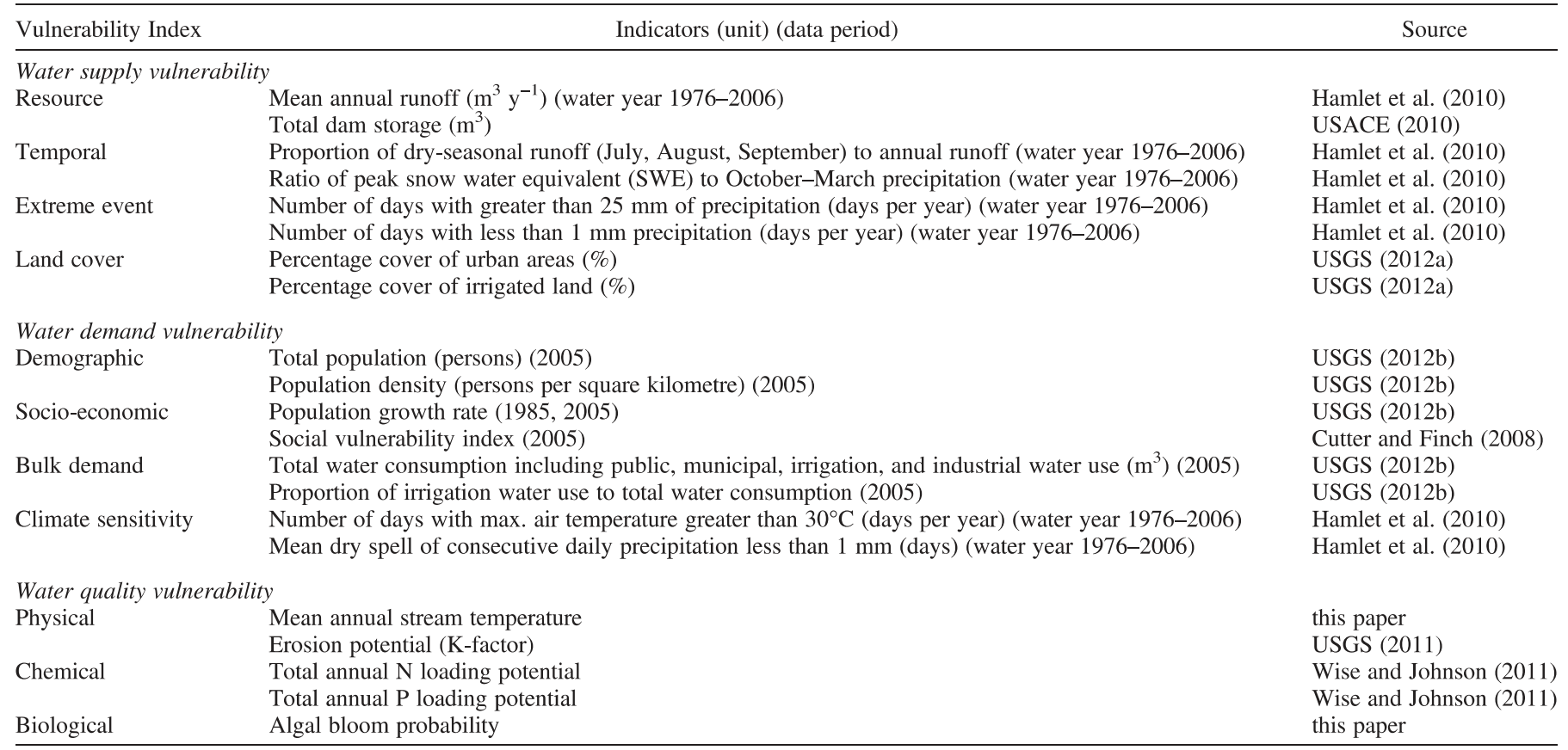




\section{4 / Heejun Chang et al.}

eight indicators (Table 1). For the calculation of 30 years of mean annual runoff and the portion of dry-seasonal runoff to annual flow, this study used water flux data simulated by the Climate Impacts Group (CIG) of the University of Washington (CIG, 2012). The water flux data were consistently generated by the Variable Infiltration Capacity (VIC) model using gridded (1/16 degree) daily climate forcing for 1915 to 2006. Although distributed runoff data do not take into account additional water supply from upstream areas and thus diversion, we considered water withdrawal potential indirectly using the dam storage capacity indicator described below. The ratio of peak snowwater equivalent to October-March precipitation (Elsner et al., 2010) was used to account for the potential vulnerability of water quantity resulting from climate change. This index can reflect the possible change in dry season water supply capacity, which is attributed to sensitivity to warming, earlier snowmelt, and less snowfall in the snow-dominated and snow-rain transient regions (Barnett, Adam, \& Lettenmaier, 2005; Mote \& Salathe, 2010). The gridded daily climate data were also applied to calculate the number of days with heavy precipitation $\left(>25 \mathrm{~mm} \mathrm{~d}^{-1}\right)$ and days with no rain $\left(<1 \mathrm{~mm} \mathrm{~d}^{-1}\right)$. The dam storage was calculated as the sum of the normal storage for all dams in each county as reported in the US National Inventory of Dams (USACE, 2010). The percentage cover of the urban area was obtained from the 2006 national land cover database of the Multi-Resolution Land Characteristics Consortium (Fry et al., 2011). The US Geological Survey (Kenny et al., 2009) provides information on the percentage cover of irrigated land at the county scale.

\section{d Water Demand Vulnerability Index}

The water demand index relates socio-economic infrastructure such as demographic, socio-economic, bulk demand, and climate sensitivity (Table 1). The amount, density, and growth rate of populations representing existing and possible water demand were collected from the US Geological Survey (USGS; Kenny et al., 2009). The USGS reports national water use information (e.g., various types of water use and population) at five-year intervals (1985 to 2005) at the county level. This study used the 2005 population data to determine total population and population density of each county. The population growth rate $(r)$ was estimated using an exponential growth model (i.e., Population_2005 $=(\mathrm{Popu}-$ lation_1985)(1+r) $)^{t}$, where $t$ is 20 years). Total water consumption was obtained from 2005 USGS water use information. Given that irrigation water use for food production is the largest water use in the CRB, we also calculated the proportion of irrigation water use to total water consumption for inclusion in this index. Regional climate characteristics can also influence the spatial and temporal pattern of municipal and irrigation water use. We chose the number of days with temperature greater than $30^{\circ} \mathrm{C}$ as a temperature indicator and mean length of dry spell (defined in Table 1) as a precipitation indicator, when both values are high there is greater water demand. The Social Vulnerability Index is a widely used metric calculated by the Hazards and Vulnerability Research Institute every five years. Factors include socio-economic, demographic and biophysical hazards; this model has been tested and is used to describe multiple dimensions of social vulnerability to hazards (Cutter \& Finch, 2008).

\section{e Water Quality Vulnerability Index}

We used five measures to create the comprehensive water quality vulnerability index, including water temperature, nutrient loading (nitrogen and phosphorus), erosion potential, and algal blooms. Although the list of potentially important water quality parameters is very long, the variables we selected encompass the physical, chemical, and biological dimensions of water quality. Many water quality variables are not included here for reasons of practicality.

Stream temperature indices were computed for each county in the CRB by aggregating reach-scale estimates of long-term mean water temperature for the Enhanced River Research File Version 2 (E2RF1) stream network (Nolan, Brakebill, Alexander, \& Schwarz, 2002) located within the Pacific Northwest region of the United States. A spatially weighted average of the reach-scale mean water temperatures was computed for each county in the CRB, thus providing one stream temperature value with which to characterize the status of stream temperatures in each county. Multiple linear regressions of measured long-term mean water temperature on reach-scale watershed attributes were used to estimate the long-term mean water temperatures for the E2RF1 stream network. The supplemental information for this paper includes further details on the water temperature analysis.

Landscape attributes were obtained for each reach-scale E2RF1 watershed (Wieczorek \& Lamotte, 2011) including mean annual total nitrogen and total phosphorus yields $\left(\mathrm{kg} \mathrm{km}^{-2} \mathrm{y}^{-1}\right)$, annual terrestrial and atmospheric nitrogen and phosphorus loadings for 2002, the area of US Environmental Protection Agency (EPA) Level III ecoregions (US EPA, 1997), and three widely recognized National Land Cover Datasets (land cover, canopy cover, and impervious surface; Fry et al., 2011). The reach-scale nitrogen and phosphorus yields were obtained from the Pacific Northwest Spatially Referenced Regressions on Watershed attributes (SPARROW) model (Wise \& Johnson, 2011). The landscape attribute data were joined to the E2RF1 reach-scale watershed polygons, which were then converted to $30 \mathrm{~m}$ rasters for use with the ArcMap Spatial Analyst software. County-scale values were then calculated using the software's Zonal Statistics tool. To measure sediment loading potential we used the $\mathrm{K}$ factor, part of the Universal Soil Loss Equation (USLE). The K factor represents the erosive potential of soil and its potential rate of runoff based on soil texture, structure, permeability, and the percentage of organic matter. The values were obtained from the State Soil Geographic database of the Natural Resources Conservation Service (USGS, 2011) and spatially averaged by county. Higher values indicate greater vulnerability to sediment pollution of surface water from upland erosion. 


\section{Water Resource Vulnerability in the Columbia River Basin / 345}

To obtain representative algal data within the appropriate time frame, we restricted data acquisition to the National Lakes Assessment (US EPA, 2009a), a representative nationwide survey of lakes, ponds, and reservoirs conducted in 2007. Waterbodies that fell within our case study regions were chosen, and overall chlorophyll $a$ (chl- $a$ ) concentrations $\left(\mu \mathrm{g} \mathrm{L}^{-1}\right)$ were obtained from the database. For each water body, we averaged areal nitrogen and phosphorus loading potential from land-based and atmospheric sources, as well as annual temperatures within the catchment to obtain representative values (from SPARROW, described above). With these data we built a general linear model relating temperature and nutrient loadings to chlorophyll concentration $(n=79)$. Briefly, chl- $a$ was influenced by both nutrients and temperature $\left(\log (y)=1.955+0.167 T+0.017 P^{2}, R_{\text {adj }}^{2}=0.32, p<\right.$ 0.001 , where $T$ is temperature, $P$ is the $\log$ areal phosphorus loading, $y$ is the chl- $a$ concentration, and $R_{\text {adj }}^{2}$ is the adjusted coefficient of determination). We then used the National Hydrography Dataset (NHD; USGS, 2004) to identify all lakes, ponds, and reservoirs in our study regions, for which we averaged nutrient loadings and annual temperatures within the catchment. We applied the aforementioned model to all the NHD water bodies to predict total chl- $a$. Finally, we identified the percentage of water bodies within each state in which model-predicted algal values exceeded World Health Organization thresholds, with moderate risk defined as chl- $a$ concentrations of $10-50 \mu \mathrm{g} \mathrm{L}^{-1}$ and high risk defined as concentrations greater than $50 \mu \mathrm{g} \mathrm{L}^{-1}$ (US EPA, 2009a); these two categories were summed to obtain our measure of water quality risk from algal blooms.

\section{f Spatial Analysis}

To determine the degree of spatial interdependence in water resource vulnerability among counties, we used local indicators of spatial autocorrelation (LISA) statistics, available in the GeoDa spatial analysis software (Anselin, Syabri, \& Kho, 2006). LISA can determine if counties with similar vulnerability are in clusters or are randomly distributed throughout the study basin (Franczyk \& Chang, 2009). This provides an evaluation of where unusual interactions occur, isolating either hotspots (areas of high local autocorrelation) or cold spots (areas of low local autocorrelation) (Anselin, 1995). LISA is expressed as:

$$
\begin{array}{r}
\operatorname{LISA}_{i}=\left(\frac{x_{i}}{m}\right) \sum_{j=1}^{n} w_{i j} x_{j}, \\
m=\sum_{i}^{n} x_{i}^{2},
\end{array}
$$

where $x_{i}$ and $x_{j}$ refer to the vulnerability of counties $i$ and $j$, respectively; $n$ is the number of counties (in this case 104 counties); $w_{i j}$ is a matrix of spatial weights, that is, if county $i$ and county $j$ are adjacent $w_{i j}=1$, otherwise $w_{i j}=0$. The significance of local spatial clustering of LISA was tested using a randomized sampling method with 999 permutations of spatial pattern at a significance level of $p \leq 0.01$. This method compares the observed clustering with the spatial patterns of 999 randomized samples. Thus, the clustering at a significance level of $p \leq 0.01$ means that overall ten of the 999 samples are not spatially randomly distributed.

\section{g Multivariate Analysis}

To assess the integrated responses of the major components of water vulnerability variability, we used non-metric multidimensional scaling (NMDS), which is a statistical technique that assesses multiple variables in different sites simultaneously and examines dissimilarities of a set of measured variables between sites. Thus, NMDS operates on a dissimilarity matrix between all pairs of sites. NMDS attempts to reduce the dimensionality of multiple variables into a small number of dimensions that minimize stress (a measure of disagreement between dissimilarities and distance between points in the ordination diagram) (Kruskal, 1964). Therefore, an NMDS plot demonstrates similarities (or dissimilarities) among different locations, with sites that are closer together in multidimensional space being more similar and sites that are farther apart being more dissimilar. NMDS preserves rank-order distances; therefore, it is useful for variables with non-normal distributions. We used Euclidean dissimilarity between water vulnerability variables in all counties; however, for pairs of variables that were highly correlated $(r>0.8)$, only a single representative variable was retained because multi-collinearity can influence ordinations. The dissimilarity matrix was ordinated on two dimensions with a randomization test $(n=200)$ to determine the significance of the ordination (Legendre \& Legendre, 1998). Stress was not substantially reduced using three dimensions; therefore, we report the two-dimensional NMDS.

\section{Results}

\section{a Water Supply Vulnerability}

The composite vulnerability of water supply is given in Fig. 2a, with higher values representing higher levels of vulnerability. The counties in the Snake River of Idaho (including counties around Twin Falls and Boise) and the Yakima River basin of Washington exhibited higher levels of vulnerability. These areas coincide with either major population centres or the basin's agricultural regions. They also relate to the higher ratio of peak snow-water equivalent to October-March precipitation. The LISA analysis identified two major hotspots- the Yakima River basin and the southern part of Idaho-all related to low dam storage, a higher number of dry days, and a higher proportion of agricultural land areas (Fig. 3a).

The spatial patterns of each indicator of water supply index differ (Fig. 4). The mean annual runoff shows vulnerable regions clustered around Yakima and Spokane, as well as around Boise and Twin Falls whereas total dam storage shows a spatially scattered pattern. Seasonal variation in runoff is higher in all of the counties around the Willamette River basin and some counties near Boise. The ratio of peak snow-water equivalent to October-March precipitation shows 
(a) Vulnerability of water supply

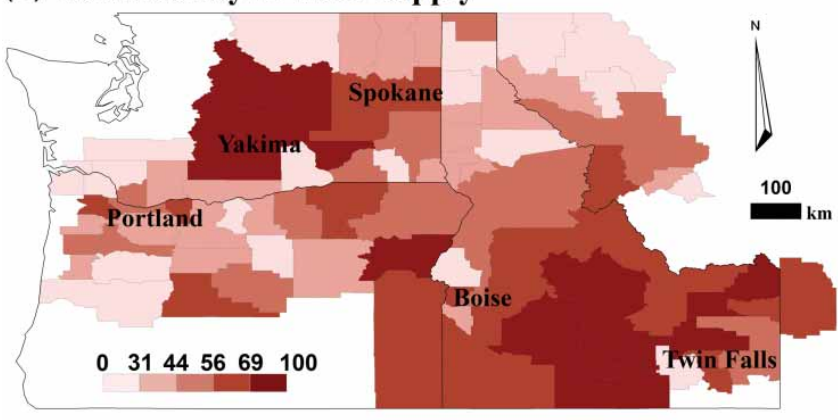

(b) Vulnerability of water demand

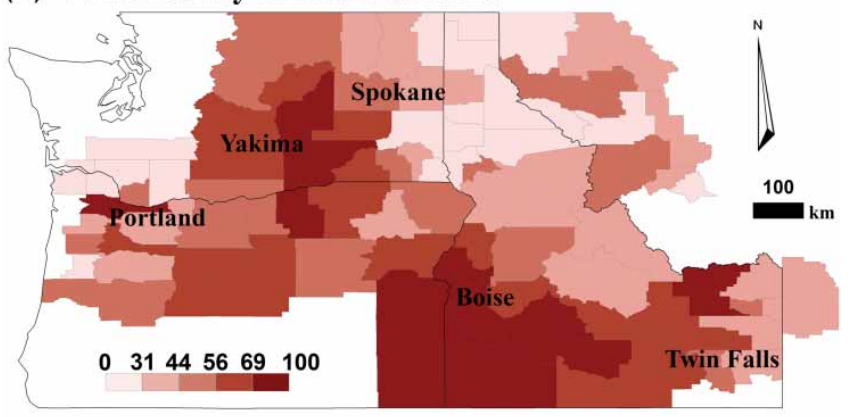

(c) Vulnerability of water quality

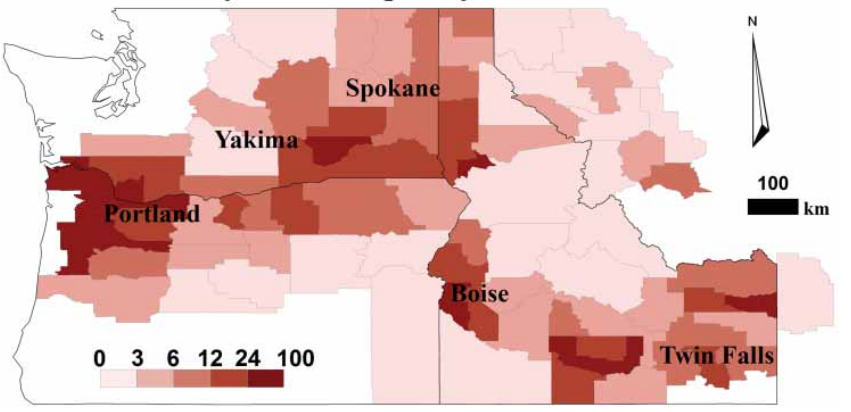

Fig. 2 Vulnerability of (a) water supply, (b) water demand, and (c) water quality, which are normalized to range from 0 to 100 . The colour legend shows the same number of counties in each quintile (20\%) for each indicator.

the opposite pattern to the mean annual runoff in most regions except the Willamette River basin. Extreme values (days with more than $25 \mathrm{~mm}$ precipitation and days with less than $1 \mathrm{~mm}$ precipitation) exhibit opposite patterns (e.g., the Portland region has a high number of days with heavy precipitation but a low number of days with no rain). All major cities have higher percentages of urban areas. The counties around Yakima, Boise, and Twin Falls are dominant irrigation areas.

However, the causes of the vulnerability of these counties are inconsistent. High vulnerability of the counties near the Snake River is attributed to lower water resource availability, a high ratio of peak snow-water equivalent to October-March precipitation, more frequent days with no rain, and a high proportion of irrigation area. On the other hand, the vulnerability of the counties in the Yakima River basin comes from frequent heavy precipitation (more than $25 \mathrm{~mm} \mathrm{~d}^{-1}$ ) and a high proportion of urban area as well as a high ratio (a) LISA cluster - Vulnerability of water supply

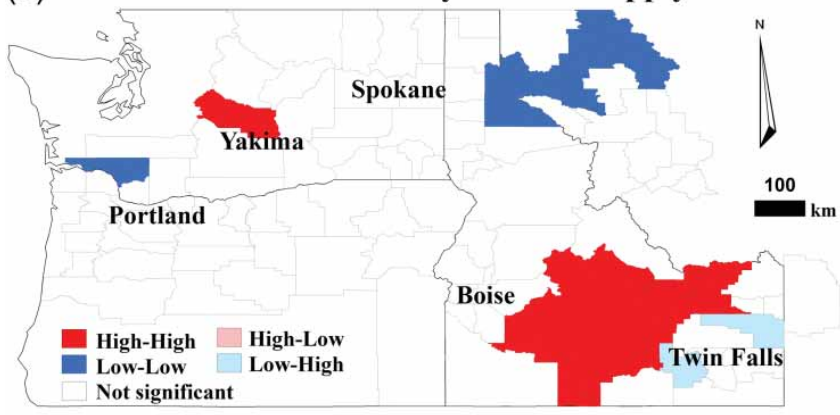

(b) LISA cluster - Vulnerability of water demand

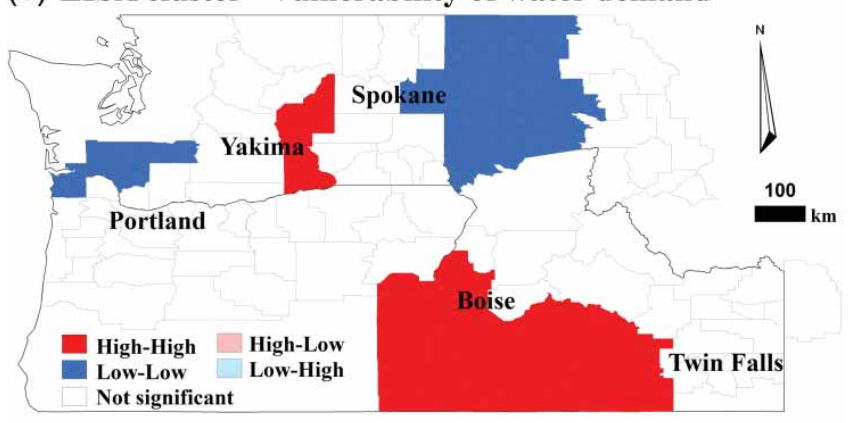

(c) LISA cluster - Vulnerability of water quality

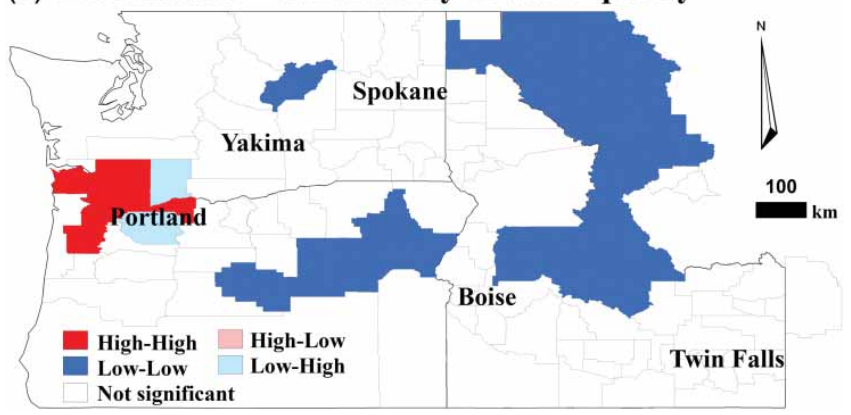

Fig. 3 Spatial cluster maps of three vulnerability indices using univariate LISA analysis with GeoDa (Arizona State University, 2012) HighHigh (Low-Low), a county with a high (low) value surrounded by counties with high (low) values, Low-High (High-Low), a county with a low (high) value surrounded by counties with high (low) values. High-High and Low-Low (Low-High and High-Low) pertain to positive (negative) spatial autocorrelation indicating spatial clustering of similar (dissimilar) values. High-High (red) refers to the hotspot and Low-Low (blue) refers to the cold spot.

of peak snow-water equivalent to October-March precipitation. The northeastern regions of the CRB show a relatively low level of vulnerability as a result of more dam storage capacity and a lower proportion of urban and irrigation lands, although they show a slightly high ratio of peak snow-water equivalent to October-March precipitation.

\section{b Water Demand Vulnerability}

The map of water demand vulnerability (Fig. 2b) has a significant resemblance to the map of water supply vulnerability (Pearson's correlation coefficient $=0.58, p<0.01$ ). The counties around major cities have a high demand vulnerability (hot spots), and 
(a) Mean annual runoff

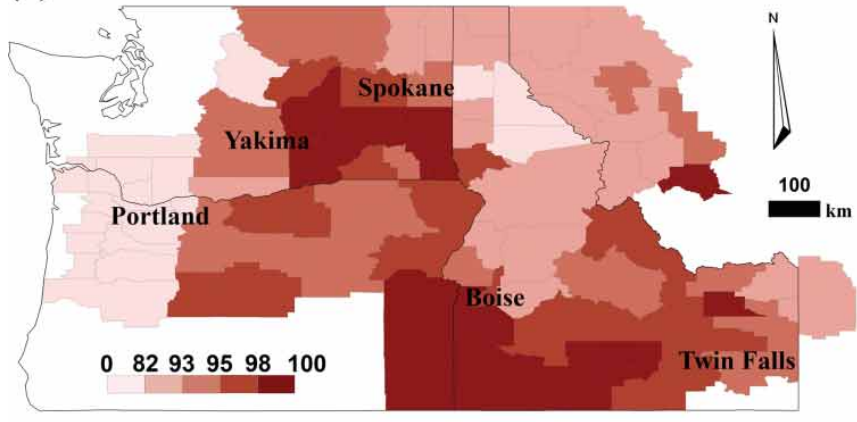

(c) Dry-seasonal runoff / annual runoff

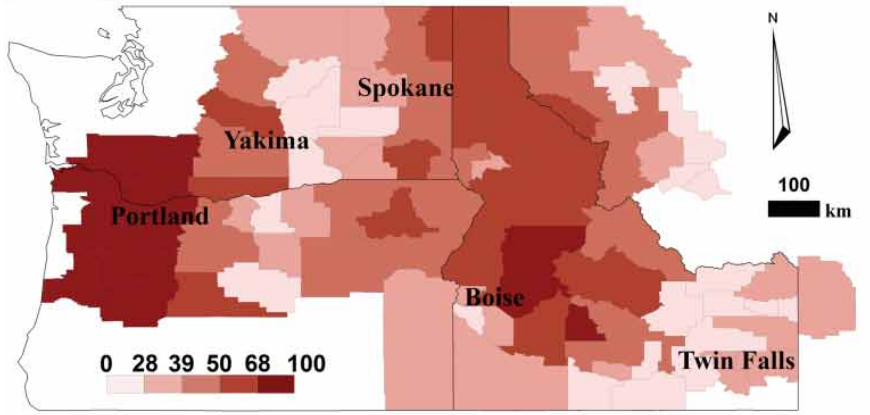

(e) Days with $>\mathbf{2 5} \mathrm{mm}$ precipitation

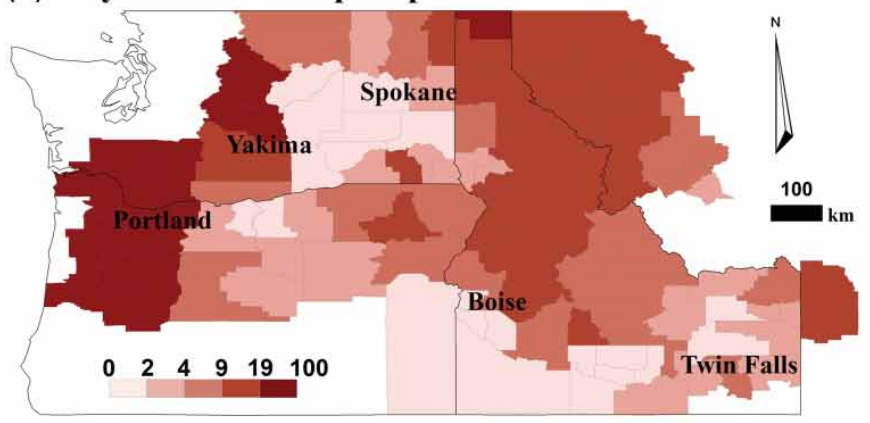

(g) \% cover of urban areas

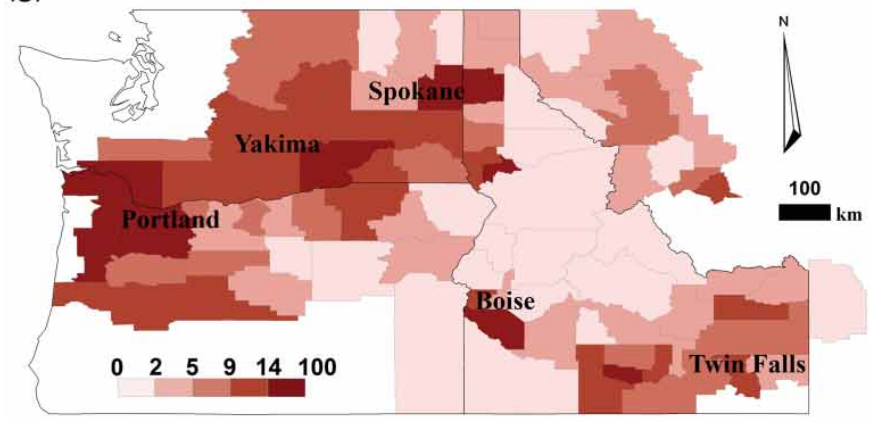

(b) Total dam storage

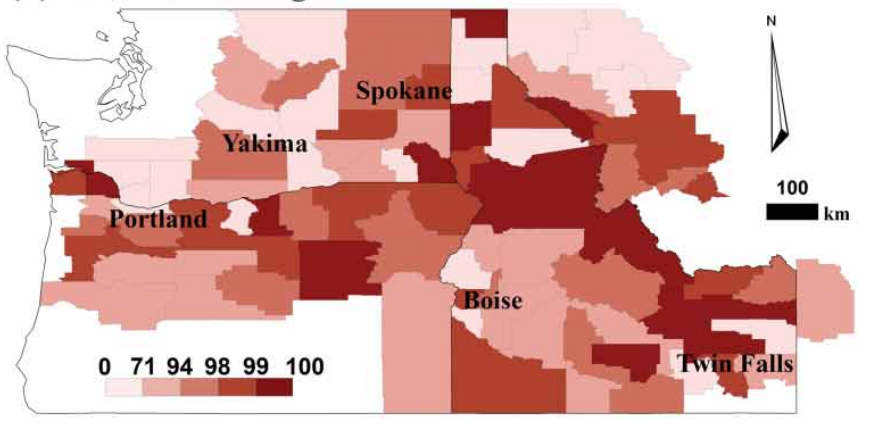

(d) Snow water equivalent / precipitation

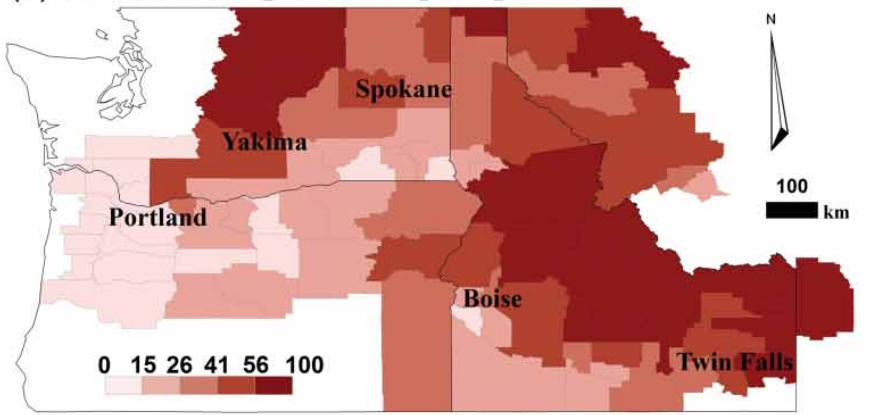

(f) Days with $<1 \mathrm{~mm}$ precipitation

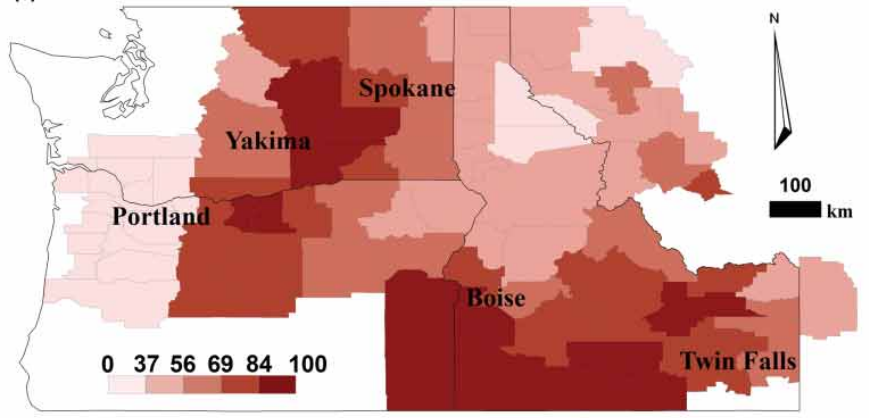

(h) \% cover of irrigation land

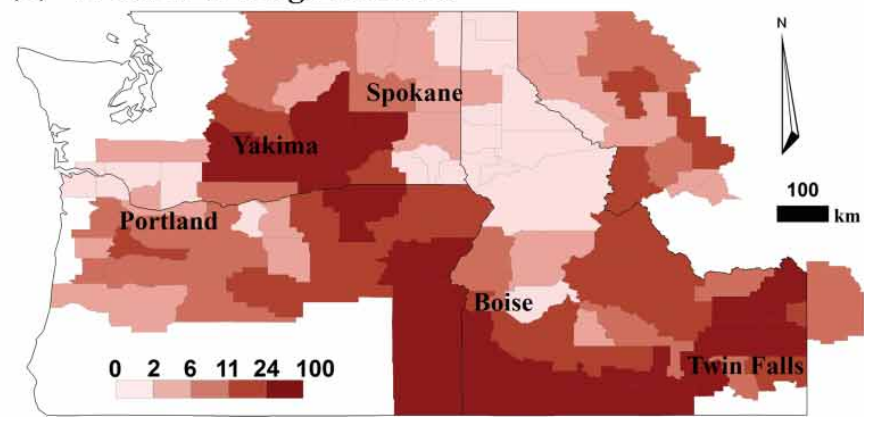

Fig. 4 Water supply vulnerability indicators normalized to range from 0 to 100. (a) Mean annual runoff and (b) total dam storage are rescaled using Eq. (2). The colour legend shows the same number of counties in each quintile (20\%) for each indicator.

the counties in the northeastern regions of the CRB display lower vulnerability (cold spots in Fig. 3b). Populations in the major cities have increased (e.g., lower Willamette River basin shows a $43 \%$ increase in 2005 compared to 1985) and are expected to rise in the future according to population projections (Baker, Richards, Sousounis, \& Brenner, 2004).

The individual demographics of water demand clearly demonstrate the close relation between water demand and 
(a) Total population

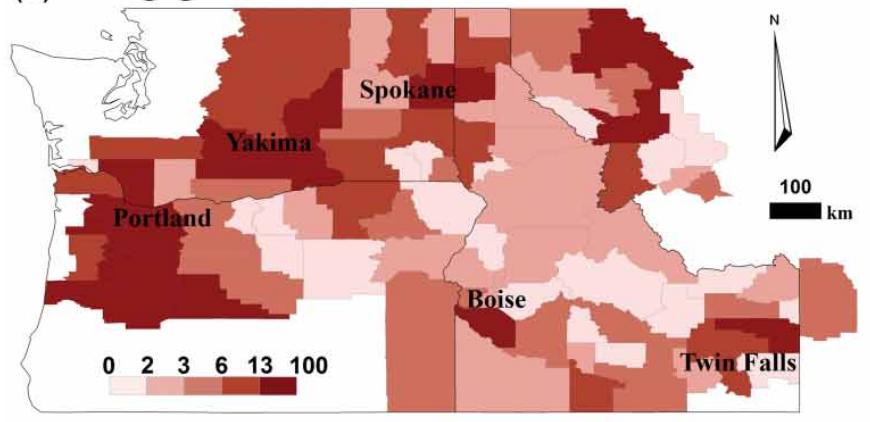

(c) Population growth rate

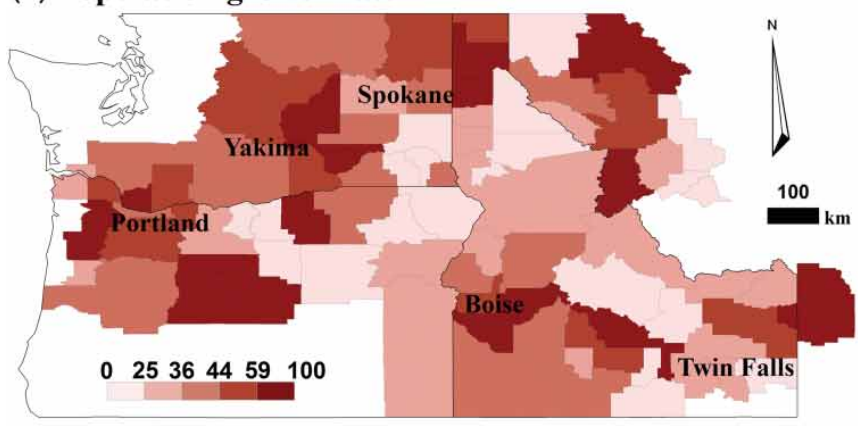

(e) Total water consumption

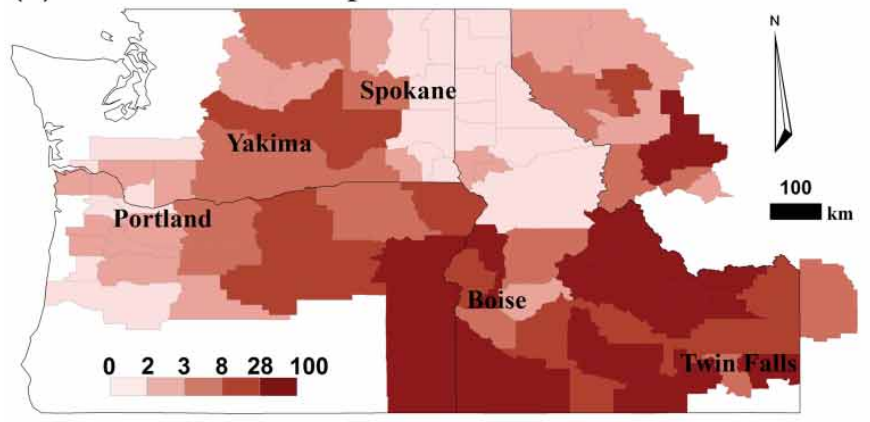

(g) Days with max. temp. $>30$ degrees $\mathrm{C}$

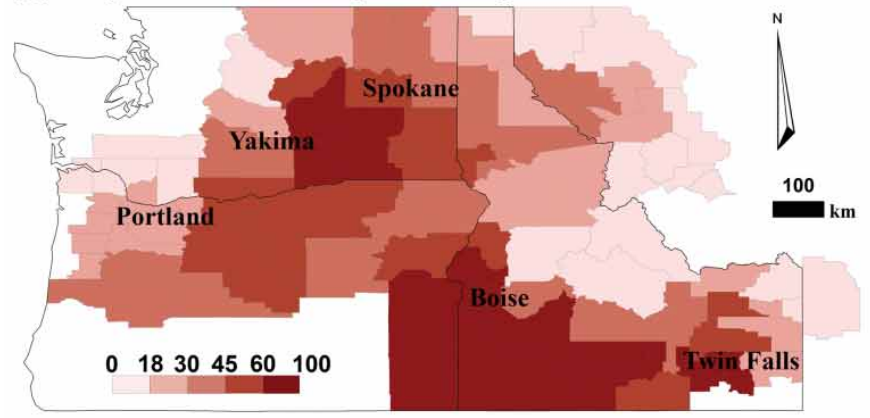

(b) Population density

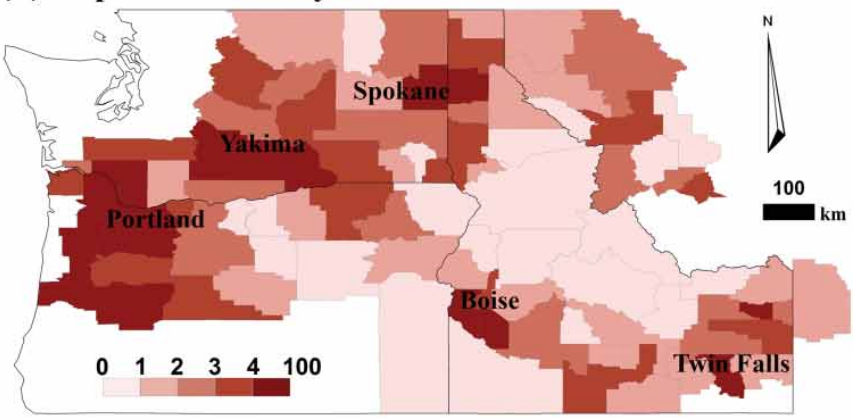

(d) Social vulnerability index

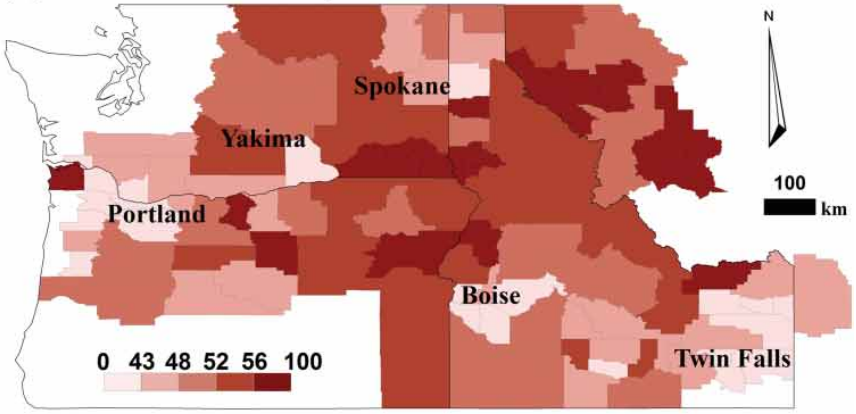

(f) Irrigation water use / total water use

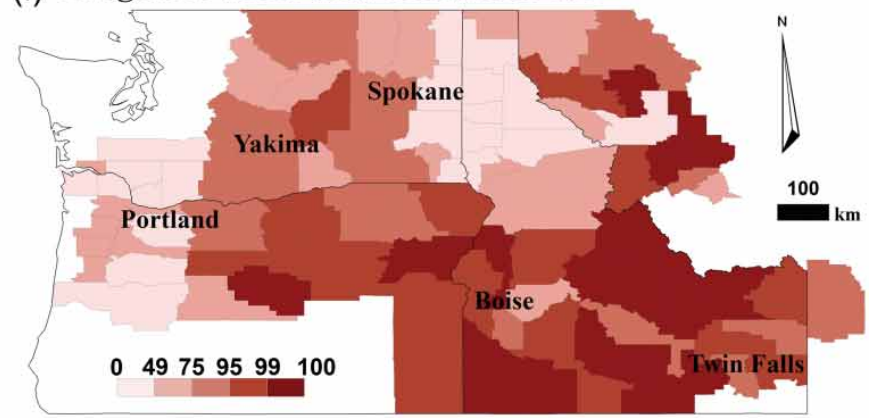

(h) Mean dry spell during the dry season

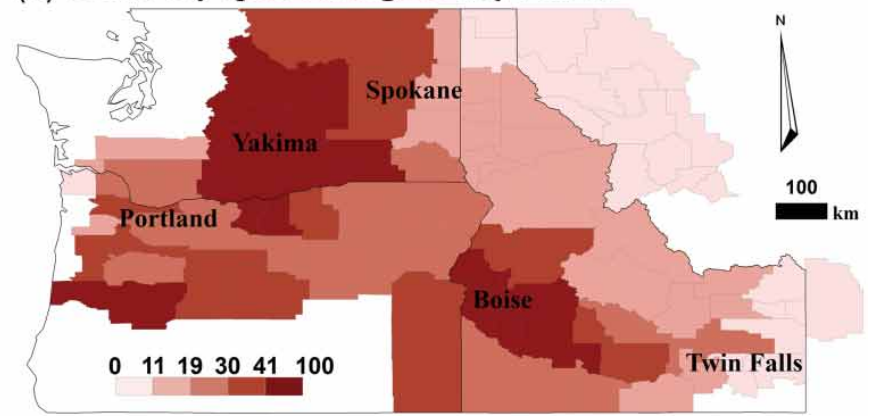

Fig. 5 Water demand vulnerability indicators normalized to range from 0 to 100 . The colour legend shows the same number of counties in each quintile (20\%) for each indicator.

urban areas (Fig. 5). The high values of total population, population density, and population growth rate have similar spatial patterns and a positive relationship with urban areas. However, the social vulnerability index, which includes income and education level, has a negative relationship with urban areas in the counties around major cities. The spatial pattern of total water consumption (Fig. 5e) is very similar to the pattern for the proportion of irrigation water 
(a) Mean annual stream temperature

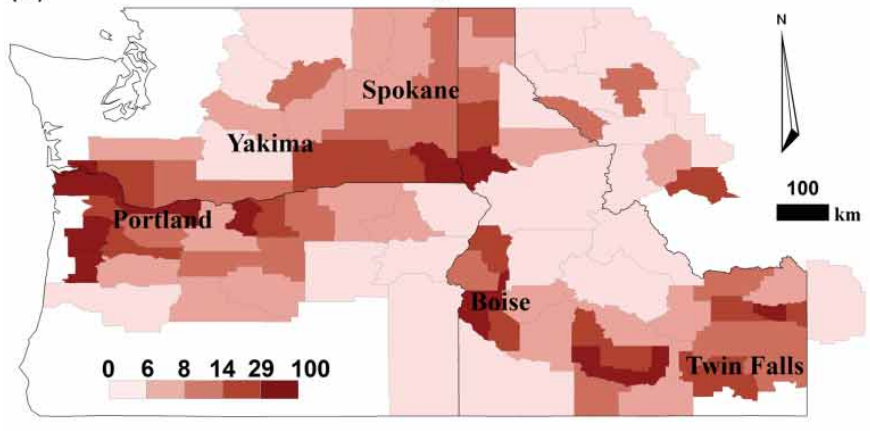

(c) Annual total nitrogen runoff

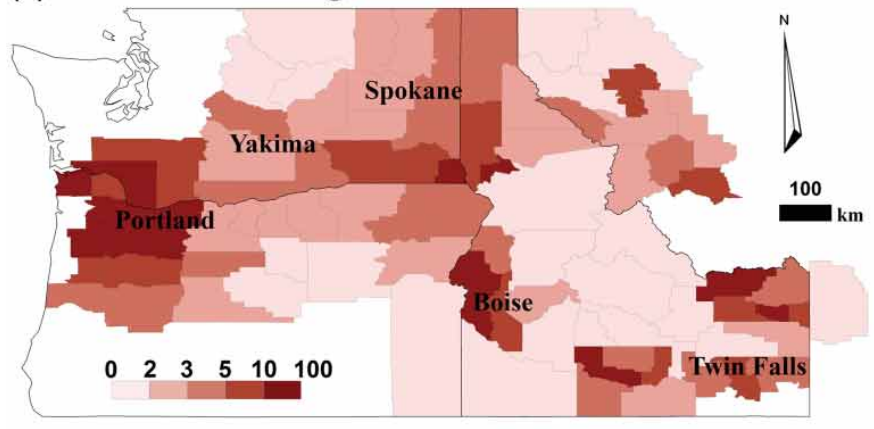

(e) Algal bloom probability

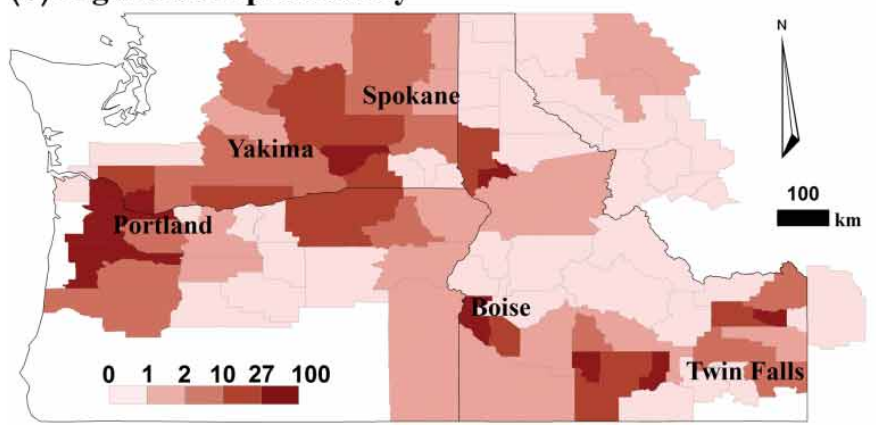

(b) Erosion potential

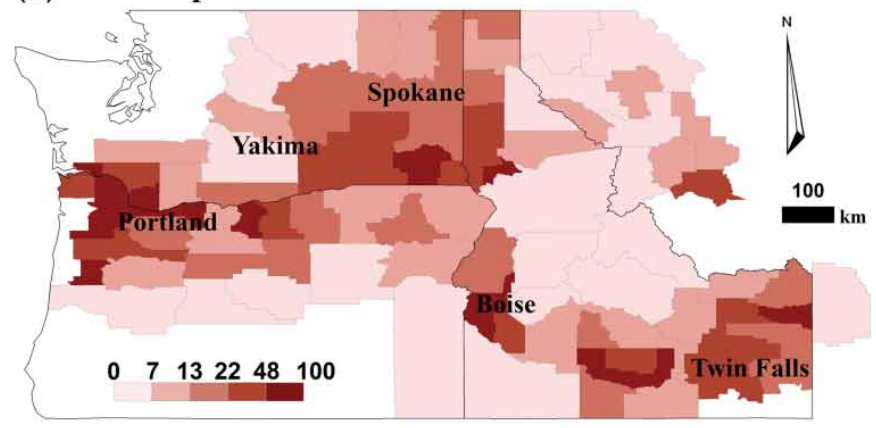

(d) Annual total phosphorus runoff

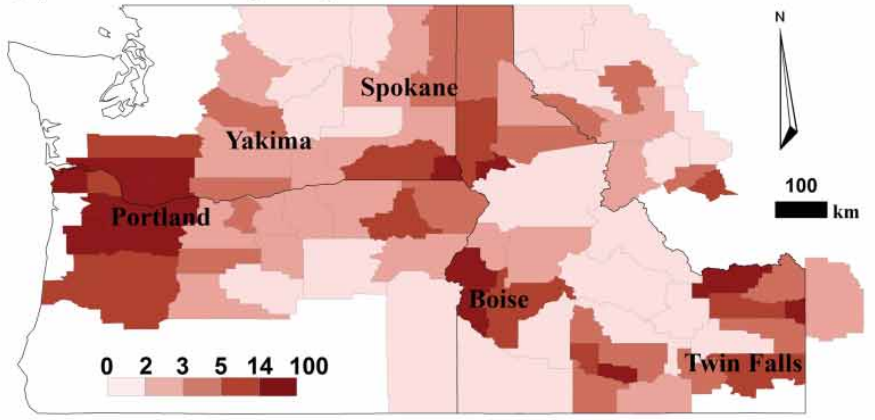

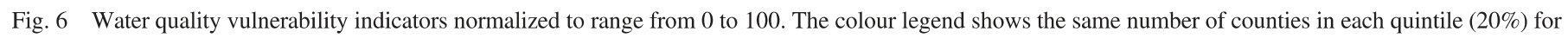
each indicator.

use to total water use (Fig. 5f), denoting that most water withdrawals are for agriculture and cultivation in the CRB. Not surprisingly, days with a maximum temperature above $30^{\circ} \mathrm{C}$ have a positive relationship with the percentage cover of irrigation land (Pearson's correlation coefficient $=$ $0.45, p<0.01$, Fig. 5h), but a negative relationship with mean annual runoff (Pearson's correlation coefficient $=$ $0.48, p<0.01$, Fig. 5a). The counties around Yakima and Boise have longer dry spells because they are located in a drier part of the CRB.

\section{c Water Quality Vulnerability}

As with demand, the water quality vulnerability indices are highest in counties near urban centres along the main stem of the Snake and Columbia rivers, responding to areas of higher urban and agricultural intensity (Fig. 2c). These few counties surrounding Portland, Oregon, and Boise, Idaho, account for most of the highest composite vulnerability scores. Agricultural regions such as Yakima, Washington, and Twin Falls, Idaho, also have counties with relatively high vulnerability, including one county in each ranking in the highest quintile along with the more urban counties. These counties also have moderately large population densities. All the remaining rural counties, which account for $60 \%$ of the counties in the study area, have moderately low to low vulnerability for water quality. In terms of regional hotspots, only the region surrounding Portland shows a significant clustering of high vulnerability counties (Fig. 3c) resulting from the combination of high population density and agricultural land use in the Willamette River basin. Counties exhibiting significant cold spots mostly occur in the more rural and drier parts of the CRB. 
350 / Heejun Chang et al.

(a) Elevation (m)

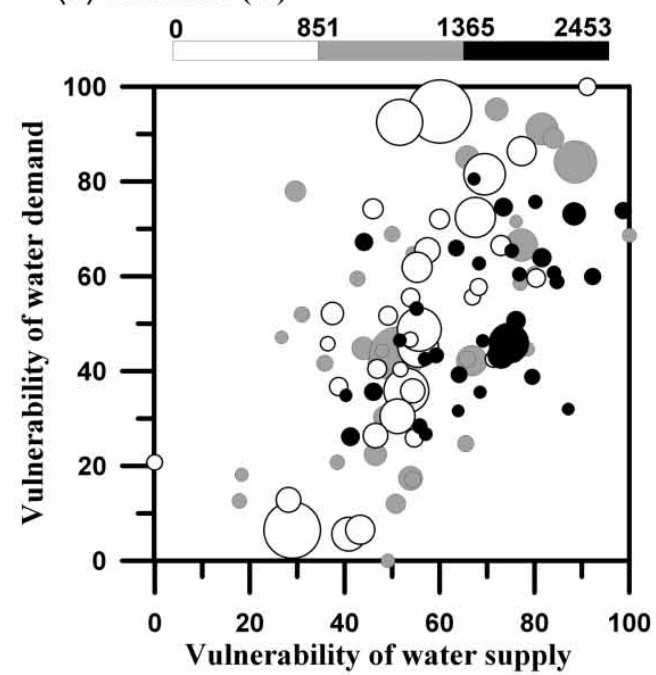

(c) Impervious area $\left(\% \times 10^{-3}\right)$

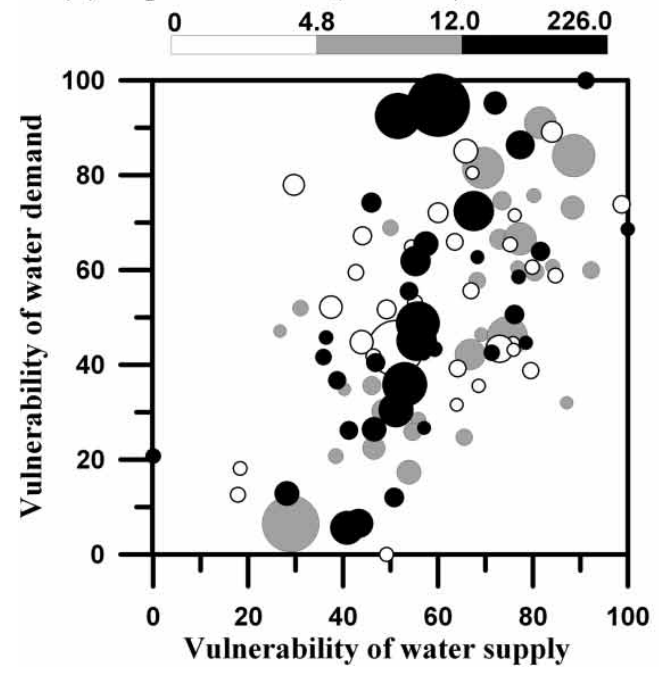

(b) Annual precipitation ( $\mathrm{mm})$

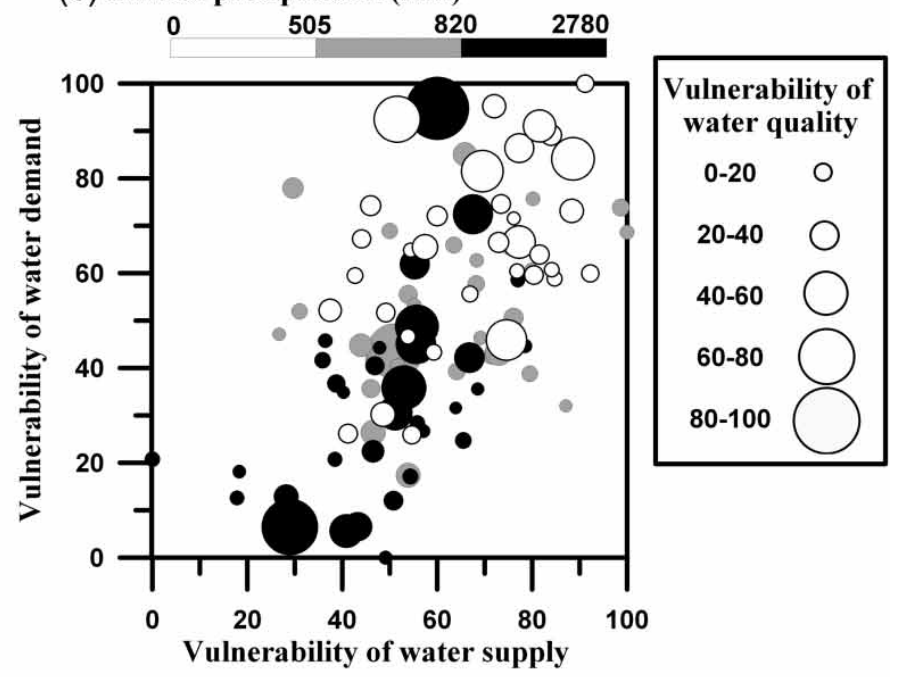

(d) Proportion of groundwater use (\%)

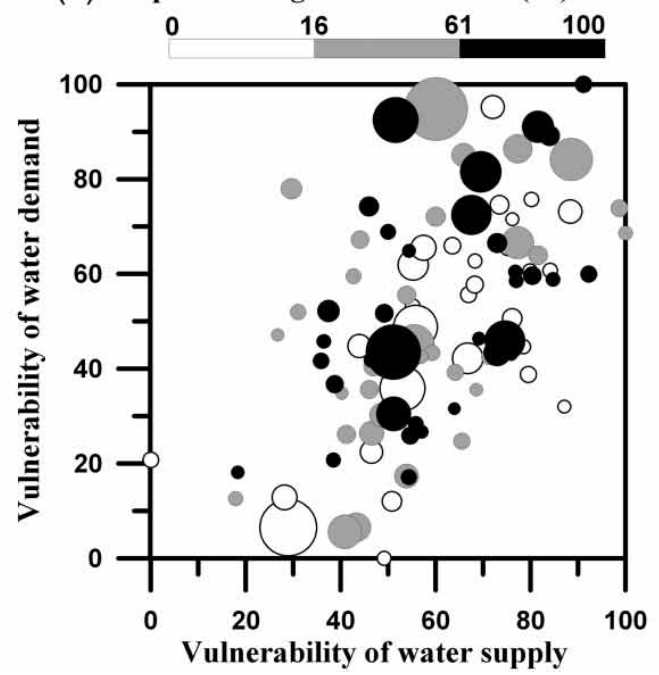

Fig. 7 Relation among vulnerability of water supply ( $x$-axis), vulnerability of water demand ( $y$-axis), and vulnerability of water quality (size of circle). The greyscale shows the ranges in (a) elevation, (b) annual precipitation, (c) impervious area, and (d) proportion of groundwater use to total water withdrawal. Categories for each plot were determined by taking the 33rd and 67th percentile values. For example, the 33rd percentile for elevation is $851 \mathrm{~m}$, whereas the 67 th percentile is $1362 \mathrm{~m}$.

The individual water quality indicators have quite similar results to each other with the more populated counties (near Portland, Boise, and Twin Falls) having the highest vulnerability scores for mean annual stream temperature, erosion potential, and nitrogen and phosphorus runoff potentials (Fig. 6). The results for algal bloom probability are slightly different in that a few counties, notably near Lewiston, Idaho, have low vulnerability scores.

\section{d Integrated Water Resource Vulnerability}

We plotted our water vulnerability indices against representative variables of three of the major controls of water vulnerability: climate, represented by elevation and precipitation; land use, represented by percentage of impervious surface areas; and management, represented by proportion of groundwater usage (Fig. 7). In general, water supply vulnerability increased with greater water demand vulnerability, as demonstrated by a positive relationship between the two vulnerability indices. However, there are no consistent relationships between water quality vulnerability and either of the two vulnerability indices. Counties with a high elevation are more clustered than counties with a low or middle elevation and exhibit medium to high vulnerability in water supply and demand (Fig. 7a). The small sizes of the black circles (i.e., high elevation counties) illustrate that these counties generally have low water quality vulnerability (Fig. 7a). Except in a few cases, counties receiving a medium amount of annual precipitation (500-820 mm) do not exhibit extreme water quality vulnerability (higher than 80) (Fig. 7b). Counties with less 

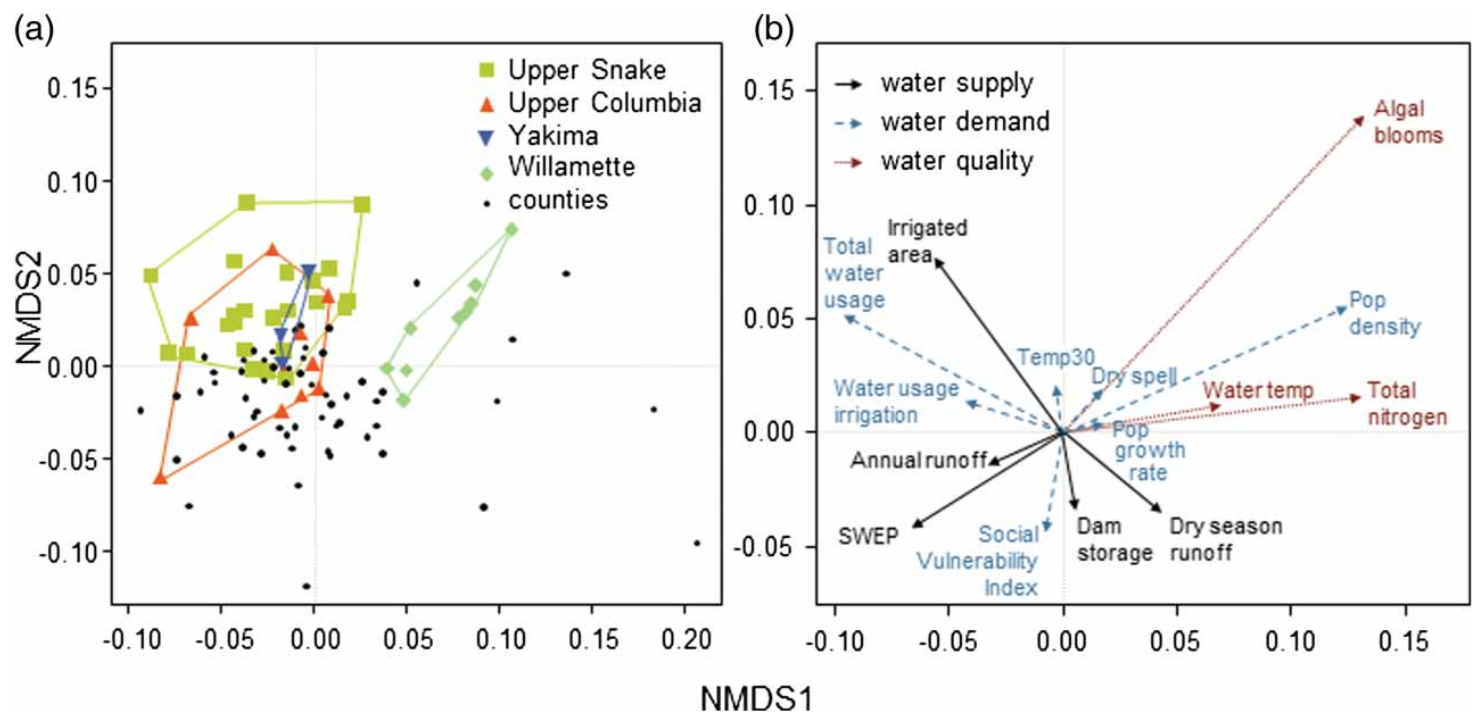

Fig. 8 Non-metric multidimensional scaling on water vulnerability variables in each county. In (a), the site scores for counties (black), highlighting counties in the Upper Snake (yellow squares), Upper Columbia (orange triangles), Yakima (blue inverted triangles), and Willamette (green diamonds) River basins. In (b), water vulnerability variables are shown as water supply (black), water demand (dashed blue), and water quality (dotted red). Panels separated simply for illustration, as are polygons drawn around counties of interest. See Table 1 for descriptions of variables in (b). Counties that are closer together in multidimensional space are similar in terms of water vulnerability variables whereas counties that are farther apart are dissimilar. For example, counties in the Willamette River basin are tightly clustered, therefore, have similar water resource vulnerability, which coincides with higher values of algal blooms and population density (in the same quadrant in panel (b)). Abbreviations: Pop = population, Temp30 = number of days when maximum air temperature exceeds $30^{\circ} \mathrm{C}, \mathrm{SWEP}=$ ratio of peak snow water equivalent (SWE) to October-March precipitation.

impervious surface area tended to have lower vulnerability to water quality (Fig. 7c). The proportion of groundwater usage has no direct relationship with any of the three vulnerability indices (Fig. 7d). This does not mean that groundwater usage is unrelated to vulnerability. Some rural counties have relied heavily on groundwater for irrigation and the over-pumping of groundwater has caused continuous declines in water levels. Water levels declined approximately $55 \mathrm{~m}$ in 26 years in Odessa, Washington, and $30 \mathrm{~m}$ in 40 years in Pendelton, Oregon (Vaccaro personal communication, 2010). These aquifers are on a trajectory to be depleted in the near future unless the current rate of pumping is markedly reduced. Agricultural areas relying on these aquifers will thus be very vulnerable.

The results of our multivariate analysis using NMDS were significant $(p=0.005)$, and stress was within an acceptable range $(14.3 \%$, stress between $10 \%$ and $20 \%$ is considered only a moderate probability of incorrect interpretation; Kruskal, 1964) (Fig. 8). NMDS illustrates important trends in our data: watersheds within the CRB will be differentially affected by components of vulnerability (i.e., threats to water vulnerability will be different in different locations), and different types of vulnerability can co-occur (i.e., some threats will co-occur with each other in different locations). Counties in the Willamette River basin were tightly clustered and, therefore, were very similar in terms of water resource vulnerability variables. Counties in the Willamette River basin were associated with water quality variables, such as total nitrogen, algal blooms, and water temperature, as well as with population density (i.e., sites in the upper right quadrant of Fig. 8a correspond to the same quadrant in Fig. $8 b)$. Counties in the Upper Snake River basin were less influenced by water quality and population variables, but they were correlated with water demand variables, such as total water usage, irrigated area, and periods of warm weather. Counties in the Upper Columbia River basin exhibited some overlap with counties in the Upper Snake River basin and were associated with high annual runoff, high water usage for irrigation, and higher ratios of peak snow-water equivalent to October-March precipitation but were negatively associated with indicators of poor water quality.

\section{Discussion and conclusions}

This study examined water resource vulnerability on a county scale using multiple indicators that encompass three major dimensions of water vulnerability: supply, demand, and quality. This study is one of the first comprehensive assessments of vulnerability conditions in the CRB, and we found that i) spatial patterns of water resource vulnerability varied noticeably in a large heterogeneous river basin; ii) major controls of spatial water resources vulnerability differed from one region to the other (e.g., Willamette River basin drivers were associated with anthropogenic effects on water quality whereas Upper Snake River basin drivers were associated with climate and land use); and iii) water supply and demand vulnerability were positively related, but there was no observable trend with respect to water quality vulnerability. Our multidimensional assessment can provide additional insights for 


\section{2 / Heejun Chang et al.}

sustainable water resource management by identifying potential drivers of water vulnerability on a county scale, which has been neglected in traditional water resource management. Below we highlight several of the factors that have direct and immediate impact on the vulnerability of the CRB.

\section{a Spatial Patterns of Vulnerability}

In general, there exists a spatial clustering of hotspot counties for all three vulnerability indices, as indicated by significant spatial autocorrelation among counties. These hotspots generally overlap with the areas identified in previous studies in the basin such as in major urban centres or agricultural areas that rely heavily on groundwater. This statistical dependence of counties provides support for evaluating the CRB as an integrated system with distinct climatic and biophysical factors, in addition to managerial and social ones. For example, the similarities between adjacent counties in the same region that have similar biophysical and climatic conditions suggest that county-scale management systems are essential for evaluating the vulnerability of the $\mathrm{CRB}$ and potentially reducing vulnerability at a regional level. In particular, the lack of a relationship between water quality vulnerability and either water supply vulnerability or water demand vulnerability suggests that regions will need to use different approaches for managing water resources.

However, it is of interest that the major hotspot for water quality vulnerability is located at the downstream reaches of the Columbia and Willamette rivers. When our water quality vulnerability map is compared with Columbia River basin toxics maps reported in a US EPA report (US EPA, 2009b), we found that the highly vulnerable areas (e.g., Willamette, Yakima, and Lower Snake rivers) identified in our study overlap considerably with the locations of contaminated fish species. These findings are in agreement with previous research that watershed disturbances originating upstream, such as agriculture, can have substantial effects on downstream catchments (Allan, 2004). Thus, greater recognition of the continuous and interconnected nature of river systems is needed. Additionally, there is a need for more watershedbased management frameworks that reflect these connections (e.g., Abell, Allan, \& Lehner, 2007).

Two managerial and social patterns describe and define some of the most pressing challenges facing the CRB. First, the spatial patterns of vulnerability vary across county and state lines, which suggests that the approach used to manage county-level supply, demand, and quality is largely determined by localized policies. Although such an approach is historical and is consistent with land use regulations focusing on individual parcels as the unit of management, these patterns highlight a need for better integrating management approaches both up- and downstream using principles of catchment management (Naiman, 1992). Second, counties with urban areas might quickly reduce vulnerability factors by building additional reservoirs, enabling high efficiency technology, restoring wetlands, or developing retention ponds and treatment plants for managing storm water and wastewater (Carpenter et al., 1998). However, rural areas and counties that ranked high on the social vulnerability index may not be able to deploy resources as quickly or extensively, which creates an uneven management landscape for decreasing vulnerability across the CRB.

\section{b Major Controls of Spatial Vulnerability and Implication for Water Resource Management}

Climate, land use, and water management systems are known to be major controls on water resources (Arnell, 1996). Not surprisingly, land use played a key role in determining water quality vulnerability. For instance, counties that have a higher proportion of agricultural areas have the highest values for erosion potential regardless of climate, be it the dry counties in Idaho or the wet counties in southwestern Washington (Fig. 4). Additionally, agricultural counties have similarly high values of erosion potential regardless of their location in a watershed (e.g., the Willamette River headwaters and mouth). Thus, we conclude that decisions about land use seem to play a larger role in water quality vulnerability than any biophysical or climate factors in the CRB. Conversely, climatic variables representing warmer temperatures and longer periods with no precipitation, as well as variables related to irrigation, were strong drivers of water demand vulnerability. Specifically, counties located in central Washington and southern Idaho were ranked as being the most vulnerable to water demand, suggesting that metrics related to human population size are far less influential than land use practices and climatic variation (Fig. 3). Finally, a combination of land use, water management, and climate were found to influence vulnerability to water supply, because highly ranked counties in the Portland area were influenced by urbanization and temporal variability in precipitation (e.g., dry season runoff and flooding) whereas counties in the Boise area were more vulnerable as a result of irrigation, drought, low runoff, and variable precipitation (Fig. 2).

A growing population will increase domestic and public water demand and will also require more food production, increasing irrigation water demand. This rising demand may exacerbate current vulnerability by increasing competition among various water users. This suggests that these regions might undergo more serious water stress than the other counties when water demand increases in the future as the climate changes and population grows (Gleick, 2003). Understanding the complexities of different water resource drivers, and the region-specific vulnerability to these drivers, allows for more informed management practices that can reduce vulnerability. For example, Cohen et al. (2006) used current measures and future scenarios of water supply and demand in the Okanagan River basin in the Canadian portion of the $\mathrm{CRB}$ to develop a range of adaptation options and processes for implementation within a water resource management framework. Additionally, the spatial clustering of hotspots of water vulnerability suggests that neighbouring counties may 


\section{Water Resource Vulnerability in the Columbia River Basin / 353}

be able to work together in addressing certain water vulnerability concerns.

\section{c Need for Synthesizing Multi-Scale Framework}

Using the county as the unit of analysis provided advantages because it represents the smallest spatial unit for integrating available biophysical and socio-economic data. Although the county allows us to assess the spatial variability of water resource vulnerability across the CRB statistically, this does not preclude the need for further analysis at scales that are either smaller or larger than the county scale. For example, various levels of vulnerability are contained within individual counties and counties also cluster to form biogeographic regions that share vulnerability characteristics. The Willamette River basin, consisting of a dozen counties, contains areas of high population density and degraded water quality variability, in agreement with previous studies (e.g., Pan et al., 2004; Pratt \& Chang, 2012). In contrast, counties in the Upper Snake River basin were less influenced by water quality and population variables but were correlated with water demand variables. On another scale, decisions by individual landowners may have varying impacts on the demand or quality parameters, particularly with respect to their proximity to surface water, in our vulnerability measurements. For example, at the parcel scale, decisions by individual residents in the Upper Columbia River basin counties may be the reason for negative associations between amount of water usage for irrigation and water quality measurements. In a large complex water basin such as the Columbia River basin, public agencies, as found in county governments, may have a direct influence on land use and other managerial dimensions of water supply; however, private land owners can exert extensive influence on water demand and impact water quality through individual decisions. Only through further coupling of the continental or biogeographic regions and parcel scales can we better understand the mechanisms behind the spatial patterns observed in this study. Indeed, multi-level water governance in the entire basin is needed to address the challenges of a changing environment caused by climate change (Hamlet, 2011). In future studies, we suggest that our analysis be linked with regional and parcel data to better evaluate the dynamics of water resource vulnerability in the CRB.

\section{d Caveats of Research and Future Research Directions}

Our results represent a first attempt at quantifying three major dimensions of water vulnerability across the CRB. Obtaining data over a spatial scale as large as the CRB comes with several caveats and challenges including biases in data collection and transformation, interdependence among indicators used, mismatches in spatial and temporal scales, and reporting of data at the most relevant scale. First, many other potential variables could have been used to reflect water vulnerability (e.g., Hamouda et al., 2009). For example, we omitted water resource management variables such as water withdrawals from the mainstem Columbia River. According to the WA
DOE (2012), there were 768 surface water rights on the Washington portion of the mainstem Columbia River with a total maximum withdrawal volume of 5.8 trillion litres of water during the growing season. Approximately $96 \%$ of the diverted water was used for irrigation. Additionally, 110 water rights exist for groundwater extractions (533 megatons per year) within $1.6 \mathrm{~km}$ of the river (Committee on Water Resources, 2004). Hence, ignoring such water diversions and extractions could induce errors in estimating county level vulnerability. Overall, a relatively small portion of the annual flow of the Columbia River is diverted to inland uses. Oregon, Washington, and Idaho divert $0.3 \%, 3 \%$, and $4 \%$ of total annual flow, respectively (Hicks, 2007).

Second, while we used separate indicators for estimating water quantity, demand, and quality vulnerability, these three factors interact with each other, and some indicators affect multiple dimensions of water vulnerability. Additionally, some indicators might be highly positively or negatively correlated with each other, potentially enhancing or cancelling each other (Connolly \& Chisholm, 1999). According to a recent Columbia River basin study projecting future water supply and demand, water supply and demand change concurrently as a result of population growth and projected shifts in temporal water availability in the CRB. For example, rising air temperature could both increase water quantity and demand vulnerability in summer by reducing snowpack, and thus summer flow, and by increasing summer water demand (WA DOE, 2011).

Third, related to interdependence among multiple indicators, the integrated composite vulnerability value also rests on the weighting scheme and scale. Although some studies explicitly solicit experts or stakeholders to propose different weights for different indicators (e.g., Sullivan, 2011), implementing such a task will require representative sampling and significant commitments from both researchers and stakeholders. Additionally, both biophysical and socio-economic data are measured at different spatial and temporal scales and so inevitably introduce uncertainties in deriving index values. For example, our decision to report at the county rather than the watershed scale reflects a pragmatic reality concerning water resources management. Despite the recognition that watersheds are biophysically integrated units (e.g., Beechie et al., 2010), very few watersheds are managed as whole entities. Further, much of the data on water usage are only reported at the county scale. As such, summarizing data at the county scale introduces an additional source of uncertainty, reflecting processes that differ across watersheds (e.g., land use practices). Future study needs to include testing the sensitivity of different weighting schemes and the influence of scale on the uncertainties of indices (Connolly \& Chisholm, 1999).

Finally, there were differences among the reporting practices of different states, restricting inferences across the entire basin. For instance, evaluation and reporting of impaired waters that violate Section 303(d) of the federal Clean Water Act were highly variable among different states (ranging from less than 


\section{4 / Heejun Chang et al.}

$3 \%$ of total stream length evaluated in Washington to more than $50 \%$ of streams assessed in Idaho). More detailed future analyses on the water resources of the CRB would benefit from coordination and standardization of procedures among agencies collecting water resource data, as well as more comprehensive studies of watersheds that cross international boundaries. Although there have been some bi-national efforts to examine transboundary water resource management issues (Cohen, Miller, Hamlet, \& Avis, 2000), better integration is needed. Thus, we recommend the creation of a central repository for water resource data for the entire CRB, which would facilitate better cross-jurisdictional cooperation and scientific understanding of this very important basin.

In summary, we recommend greater synthesis between a fine-scaled management unit (e.g., the county level jurisdictional unit in the United States) and a more integrative biophysical unit (e.g., the watershed or basin). We also suggest that use of a multidimensional assessment of water vulnerability provides a more robust estimate of ongoing and potential water supply, demand, and quality concerns at the regional scale, as illustrated in this paper. With expected climate change and population growth, adaptive integrated water resource management in the whole basin can only be achieved by close collaboration among scientists, water managers, land owners, and policy-makers in the CRB across multiple scales.

\section{Acknowledgements}

This research was supported by a summer collaborative project program of the Institute for Sustainable Solutions at Portland State University (PSU). This material is also partially based upon work supported by the National Science Foundation under Grant No. 1038925. Any opinions, findings, and conclusions or recommendations expressed in this material are those of the author(s) and do not necessarily reflect the views of PSU or the National Science Foundation. We thank two anonymous reviewers for constructive feedback.

\section{References}

Abell, R., Allan, J. D., \& Lehner, B. (2007). Unlocking the potential of protected areas for freshwaters. Biological Conservation, 134, 48-63.

Alcamo, J., Dronin, N., Endejan, M., Golubev, G., \& Kirilenkoc, A. (2007). A new assessment of climate change impacts on food production shortfalls and water availability in Russia. Global Environmental Change, 17, 429-444.

Ali, M. H., \& Adham, A. K. M. (2007). Impact of climate change on crop water demand and its implication on water resources planning: Bangladesh perspective. Journal of AgroMeteorology, 9, 20-25.

Allan, J. D. (2004). Landscapes and riverscapes: The influence of land use on stream ecosystems. Annual Review of Ecology, Evolution, and Systematics, 35, 257-284.

Anselin, L. (1995). Local indicators of spatial association - LISA. Geographical Analysis, 27, 93-115.

Anselin, L., Syabri, I., \& Kho, Y. (2006). GeoDa: An introduction to spatial data analysis. Geographical Analysis, 38, 5-22.

Arizona State University. (2012). GeoDa Center for Geospatial Analysis and Computation. Retrieved from the School of Geographical Sciences and Urban Planning website: https://geodacenter.asu.edu/

Arnell, N. (1996). Global warming, river flows and water resources. New York: Wiley.

Arthington, A. H., Bunn, S. E., Poff, N. L., \& Naiman, R. J. (2006). The challenge of providing environmental flow rules to sustain river ecosystems. Ecological Applications, 16, 1311-1318.

Baker, M. J., Richards, P. L., Sousounis, P. J., \& Brenner, A. J. (2004). Alternative futures for the Willamette river basin, Oregon. Ecological Applications, 14, 313-324.

Barnett, T. P., Adam, J. C., \& Lettenmaier, D. P. (2005). Potential impacts of a warming climate on water availability in snow-dominated regions. Nature, 438, 303-309.

Beechie, T. J., Sear, D. A., Olden, J. D., Pess, G. R., Buffington, J. M., Moir, H., ... Pollock, M. M. (2010). Process-based principles for restoring river ecosystems. BioScience, 60, 209-222.

Bougadis, J., Adamowski, K., \& Diduch, R. (2005). Short-term municipal water demand forecasting. Hydrological Processes, 19, 137-148.

Breyer, B., Chang, H., \& Prandvash, H. (2012). Land-use, temperature and single-family residential water use patterns in Portland, Oregon and Phoenix, Arizona. Applied Geography, 35, 142-151.

Brodersen, J. J., Rodriguez-Gil, L., Jonsson, M., Hansson, L. A., Bronmark, C., Nilsson, P. A., ... Berglund, O. (2011). Temperature and resource availability may interactively affect over-wintering success of juvenile fish in a changing climate. PLOS ONE, 6, e24022. doi:10.1371/journal. pone. 0024022

Camargo, J. A., \& Alonso, A. (2006). Ecological and toxicological effects of inorganic nitrogen pollution in aquatic ecosystems: A global assessment. Environment International, 32, 831-849.

Carpenter, S. R., Caraco, N. F., Correll, D. L., Howarth, R. W., Sharpley, A. N., \& Smith, V. H. (1998). Nonpoint pollution of surface waters with phosphorus and nitrogen. Ecological Applications, 8, 559-568.

Chang, H. (2007). Streamflow characteristics in urbanizing basins in the Portland Metropolitan Area, Oregon, USA. Hydrological Processes, 21(2), 211-222.

Chang, H., \& Jung, I. W. (2010). Spatial and temporal changes in runoff caused by climate change in a complex large river basin in Oregon. Journal of Hydrology, 388(3-4), 186-207.

Chang, H., Jung, I. W., Steele, M., \& Gannett, M. (2012). Spatial patterns of March and September streamflow trends in Pacific Northwest streams. Geographical Analysis, 44, 177-201.

Chang, H., Lafrenz, M., Jung, I. W., Figliozzi, M., Platman, D., \& Pederson, C. (2010). Potential impacts of climate change on flood-induced travel disruption: A case study of Portland in Oregon, USA. Annals of the Association of American Geographers, 100(4), 938-952.

Chaves, H. M. L., \& Alipaz, S. (2007). An integrated indicator based on basin hydrology, environment, life, and policy: The watershed sustainability index. Water Resources Management, 21, 883-895.

CIG (Climate Impacts Group). (2012). Primary data. Retrieved from http:// warm.atmos.washington.edu/2860/products/primary_data/

Cohen, S., Neilsen, D., Smith, S., Neale, T., Taylor, B., Barton, M., ... Langsdale, S. (2006). Learning with local help: Expanding the dialogue on climate change and water management in the Okanagan Region, British Columbia, Canada. Climatic Change, 75, 331-358.

Cohen, S. J., Miller, K. A., Hamlet, A. F., \& Avis, W. (2000). Climate change and resource management in the Columbia River basin. Water International, 25, 253-272.

Committee on Water Resources. (2004). Managing the Columbia River: Instream flows, water withdrawals, and salmon survival. Washington, DC: The National Academies Press.

Connolly, C., \& Chisholm, M. (1999). The use of indicators for targeting public expenditure: The Index of Local Deprivation. Environment and Planning C: Government and Policy, 17, 463-482. 


\section{Water Resource Vulnerability in the Columbia River Basin / 355}

Correll, D. L., Jordan, T. E., \& Weller, D. E. (1992). Nutrient flux in a landscape: Effects of coastal land use and terrestrial community mosaic on nutrient transport to coastal waters. Estuaries, 15, 431-442.

Cutter, S. L., \& Finch, C. (2008). Temporal and spatial changes in social vulnerability to natural hazards. Proceedings of the National Academy of Sciences of the United States of America, 105, 2301-2306.

De Sherbinin, A., Schiller, A., \& Pulsipher, A. (2007). The vulnerability of global cities to climate hazards. Environment \& Urbanization, 19, 39-64

Dettinger, M. (2011). Climate change, atmospheric rivers, and floods in California-A multimodel analysis of storm frequency and magnitude changes. Journal of the American Water Resources Association, 47, 514-523.

Doll, P., \& Zhang, J. (2010). Impact of climate change on freshwater ecosystems: A global-scale analysis of ecologically relevant river flow alterations. Hydrology and Earth System Sciences, 14, 783-799.

Doyle, M. W., Stanley, E. H., Havlick, D. G., Kaiser, M., Steinbauch, G., Graf, W. L., ... Riggsbee, J. A. (2008). Aging infrastructure and ecosystem restoration. Science, 319(5861), 286-287.

Elsner, M. M., Cuo, L., Voisin, N., Deems, J. S., Hamlet, A. F., Vano, J. A., ... Lettenmaier, D. P. (2010). Implications of 21 st century climate change for the hydrology of Washington State. Climatic Change, 102, 225-260.

Falkenmark, M. (2008). Water and sustainability: A reappraisal. Environment, 50, 4-16.

Falloon, P., \& Betts, R. (2010). Climate impacts on European agriculture and water management in the context of adaptation and mitigation-The importance of an integrated approach. Science of the Total Environment, 408, $5667-5687$

Franczyk, J., \& Chang, H. (2009). Spatial analysis of water use in Oregon, USA, 1985-2005. Water Resources Management, 23(4), 755-774.

Fry, J., Xian, G., Jin, S., Dewitz, J., Homer, C., Yang, L., ... Wickham, J. (2011). Completion of the 2006 National Land Cover Database for the conterminous United States. Photogrammetric Engineering \& Remote Sensing, 77(9), 858-864.

Gleick, P. H. (2003). Global freshwater resources: Soft-path solutions for the 21 st century. Science, 302(5650), 1524-1528.

Gober, P., Kirkwood, C., Balling, R. C., Jr., Ellis, A. W., \& Deitrick, S. (2010). Water planning under climate uncertainty in Phoenix: Why we need a new paradigm. Annals of the Association of American Geographers, 100(2), 356-372.

Halmstad, A., Najafi, M. R., \& Moradkhani, H. (2012). Analysis of precipitation extremes with the assessment of regional climate models over the Willamette River Basin, USA. Hydrological Processes, Advance online publication. doi:10.1002/hyp.9376

Hamlet, A. F. (2011). Assessing water resources adaptive capacity to climate change impacts in the Pacific Northwest region of North America Hydrology and Earth System Sciences, 15, 1427-1443.

Hamlet, A. F., Carrasco, P., Deems, J., Elsner, M. M., Kamstra, T., Lee, C., ... Whitely Binder, L. (2010). Final project report for the Columbia Basin Climate Change Scenarios Project. Retrieved from http://www.hydro. washington.edu/2860/report/

Hamlet, A. F., \& Lettenmaier, D. P. (2007). Effects of 20th century warming and climate variability on flood risk in the western U.S. Water Resources Research, 43, 17.

Hamouda, M. A., El-Din, M. M. N., \& Moursy, F. I. (2009). Vulnerability assessment of water resources systems in the Eastern Nile Basin. Water Resources Management, 23, 2697-2725

Hester, E. T., \& Doyle, M. W. (2011). Human impacts to river temperature and their effects on biological processes: A quantitative synthesis. Journal of the American Water Resources Association, 47, 571-587.

Hicks, W. (2007). Columbia River diversion as a public revenue source. White paper to Oregon State Senator David Nelson. Retrieved from http:// aquadoc.typepad.com/waterwired/files/Columbia_River_Revenue.pdf

Hitzfeld, B. C., Hoger, S. J., \& Dietrich, D. R. (2000). Cyanobacterial toxins: Removal during drinking water treatment, and human risk assessment. Environmental Health Perspectives, 108, 113-122.
House-Peters, L., \& Chang, H. (2011a). Modeling the impact of land use and climate change on neighborhood-scale evaporation and nighttime cooling: A surface energy balance approach. Landscape and Urban Planning, 103, 139-155.

House-Peters, L., \& Chang, H. (2011b). Urban water demand modeling: Review of concepts, methods, and organizing principles. Water Resources Research, 47(W05401). doi:10.1029/2010WR009624

Jun, K. S., Chung, E. S., Sung, J. Y., \& Lee, K. S. (2011). Development of spatial water resources vulnerability index considering climate change impacts. Science of the Total Environment, 409, 5228-5242.

Jung, I. W., \& Chang, H. (2011). Climate change impacts on spatial patterns in drought risk in the Willamette River Basin, Oregon, USA. Theoretical and Applied Climatology, 108, 355-371.

Kenny, J. F., Barber, N. L., Hutson, S. S., Linsey, K. S., Lovelace, J. K., \& Maupin, M. A. (2009). Estimated use of water in the United States in 2005. U.S. Geological Survey Circular 1344, Reston, VA

Kruskal, J. B. (1964). Nonmetric multidimensional scaling: A numerical method. Psychometrika, 29, 115-129.

Lane, S. N., Tayefi, V., Reid, S. C., Yu, D., \& Hardy, R. J. (2007). Interactions between sediment delivery, channel change, climate change and flood risk in a temperate upland environment. Earth Surface Processes and Landforms, 32, 429-446.

Legendre, P., \& Legendre, L. (1998). Numerical ecology. Amsterdam, The Netherlands: Elsevier.

Leurs, A. L. (2005). The surface of vulnerability: An analytical framework. Global Environmental Change, 15, 214-223.

Madadgar, S., \& Moradkhani, H. (2012). Drought analysis under climate change using copula. Journal of Hydrologic Engineering, Advance online publication. doi: org/10.1061/(ASCE)HE.1943-5584.0000532

Maier, H. R., Lence, B. J., Tolson, B. A., \& Foschi, R. O. (2001). First-order reliability method for estimating reliability, vulnerability, and resilience. Water Resources Research, 37(3), 779-790.

Makarewicz, J. C., Lewis, T. W., Bosch, I., Noll, M. R., Herendeen, N., Simon, R. D., .. Vodacek, A. (2009). The impact of agricultural best management practices on downstream systems: Soil loss and nutrient chemistry and flux to Conesus Lake, New York, USA. Journal of Great Lakes Research, 35, 23-36.

Manandhar, S., Pandey, V. P., \& Kazama, F. (2012). Application of Water Poverty Index (WPI) in Nepalese context: A case study of Kali Gandaki River Basin (KGRB). Water Resources Management, 26, 89-107.

Mantua, N., Tohver, I., \& Hamlet, A. (2010). Climate change impacts on streamflow extremes and summertime stream temperature and their possible consequences for freshwater salmon habitat in Washington State. Climatic Change, 102, 187-223.

McCarthy, J. J. (2001). Climate change 2001: Impacts, adaptation, and vulnerability: contribution of Working Group II to the third assessment report of the Intergovernmental Panel on Climate Change. Cambridge: Cambridge University Press.

Metzger, M. J., Leemans, R., \& Schröter, D. (2005). A multidisciplinary multiscale framework for assessing vulnerabilities to global change. International Journal of Applied Earth Observation and Geoinformation, 7, 253-267.

Moradkhani, H., Baird, R. G., \& Wherry, S. (2010). Impact of climate change on floodplain mapping and hydrologic ecotones. Journal of Hydrology, 395, 264-278.

Mote, P. W., \& Salathe, E. P. (2010). Future climate in the Pacific Northwest. Climatic Change, 102, 29-50.

Naiman, R. J. (1992). Watershed management: Balancing sustainability and environmental change. New York, NY, USA: Springer-Verlag.

Najafi, M. R., Moradkhani, H., \& Jung, I. (2011). Assessing the uncertainties of hydrologic model selection in climate change impact studies Hydrological Processes, 25, 2814-2826.

Nilsson, C., Reidy, C. A., Dynesius, M., \& Revenga, C. (2005). Fragmentation and flow regulation of the world's large river systems. Science, 308, 405-408.

Nolan, J. V., Brakebill, J. W., Alexander, R. B., \& Schwarz, G. E. (2002). Enhanced River Reach File 2 (US Geological Survey Open-File Report 02-40). Reston, VA. 


\section{6 / Heejun Chang et al.}

Pan, Y. D., Herlihy, A., Kaufmann, P., Wigington, J., Van Sickle, J., \& Moser, T. (2004). Linkages among land-use, water quality, physical habitat conditions and lotic diatom assemblages: A multi-spatial scale assessment. Hydrobiologia, 515, 59-73.

Poff, N. L., Allan, J. D., Bain, M. B., Karr, J. R., Prestegaard, K. L., Richter, B. D., ... Stromberg, J. C. (1997). The natural flow regime. BioScience, 47, 769-784.

Polsky, C., Neff, R., \& Yarnal, B. (2007). Building comparable global change vulnerability assessments: The vulnerability scoping diagram. Global Environmental Change, 17, 472-485.

Praskievicz, S., \& Chang, H. (2011). Impacts of climate change and urban development on water resources in the Tualatin River basin, Oregon. Annals of the Association of American Geographers, 101(2), 249-271.

Pratt, B., \& Chang, H. (2012). Effects of land cover, topography, and built structure on seasonal water quality at multiple spatial scales. Journal of Hazardous Materials, 209/210, 48-58

Reid, L., \& Dunne, T. (2003). Sediment budgets as an organizing framework in fluvial geomorphology. In G. Kondolf \& H. Piegay (Eds.), Tools in fluvial geomorphology (pp. 463-500). Chichester, England: John Wiley \& Sons Ltd.

Risley, J., Moradkhani, H., Hay, L., \& Markstrom, S. (2011). Statistical trends in watershed scale response to climate change in selected basins across the United States. Earth Interactions, 15, 617-633.

Saunders, J. F., Murphy, M., Clark, M., \& Lewis, M. L. (2004). The influence of climate variation on the estimation of low flows used to protect water quality: A nationwide assessment. Journal of the American Water Resources Association, 40, 1339-1349.

Shandas, V., \& Alberti, M. (2009). Exploring the role of vegetation fragmentation on aquatic conditions: Linking upland with riparian areas in Puget Sound lowland streams. Landscape and Urban Planning, 60, 66-75.

Shandas, V., \& Parandvash, G. H. (2010). Integrating urban form and demographics in water demand management: An empirical case study of Portland Oregon. Environment and Planning B: Planning and Design, $37,112-128$.

Sharpley, A. N., Chapra, S. C., Wedepohl, R., Sims, J. T., Daniel, T. C., \& Reddy, K. R. (1994). Managing agricultural phosphorus for protection of surface waters - issues and options. Journal of Environmental Quality, 23, 437-451.

Sivakumar, B. (2011). Global climate change and its impacts on water resources planning and management: Assessment and challenges. Stochastic Environmental Research and Risk Assessment, 25, 583-600.

Smith, V. H. (1998). Cultural eutrophication of inland, estuarine, and coastal waters. In M. L. Pace \& P. M. Groffman (Eds.), Successes, limitations, and frontiers in ecosystem science (pp. 7-49). New York, USA: SpringerVerlag.

Snyder, M. N., Goetz, S. J., \& Wright, R. K. (2005). Stream health rankings predicted by satellite derived land cover metrics. Journal of the American Water Resources Association, 41, 659-677.

Sonoda, K., \& Yeakley, J. A. (2007). Relative effects of land use and nearstream chemistry on phosphorus in an urban stream. Journal of Environmental Quality, 36, 144-154.

Sullivan, C. A. (2011). Quantifying water vulnerability: A multi-dimensional approach. Stochastic Environmental Research and Risk Assessment, 25, 627-640.

Sullivan, C. A., Meigh, J. R., Giacomello, A. M., Fediw, T., Lawrence, P., Samad, M., ... Steyl, I. (2003). The Water Poverty Index: Development and application at the community scale. Natural Resources Forum, 27, 189-199.

Tang, L., Yang, D., Heping, H., \& Gao, B. (2011). Detecting the effect of land-use change on streamflow, sediment and nutrient losses by distributed hydrological simulation. Journal of Hydrology, 409, 172-182.
Trimble, S. W., \& Lund, S. W. (1982). Soil conservation in the Coon Creek Basin, Wisconsin. Journal of Soil and Water Conservation, 37, 355-356.

Turner, B. L., Kasperson, R. E., Matsone, P. A., Mccarthy, J. J., Corell, R. W., Christensene, L., ... Schiller, A. (2003). A framework for vulnerability analysis in sustainability science. Proceedings of the National Academy of Sciences of the United States of America, 100, 8074-8079.

Udawatta, R. P., Krstansky, J. J., Henderson, G. S., \& Garrett, H. E. (2002). Agroforestry practices, runoff, and nutrient loss: A paired watershed comparison. Journal of Environmental Quality, 31, 1214-1225.

USACE (US Army Corps of Engineers). (2010). National inventory of dams. U.S. Army Corps of Engineers. Retrieved from http://www.iwr.usace.army. mil/index.php/missions/flood-risk-management/national-inventory-of-dams

US EPA (US Environmental Protection Agency). (1997). Level III ecoregions of the conterminous United States (Revision of Omernik, 1987). U.S. Environmental Protection Agency, National Health and Environmental Effects Research Laboratory MAP M-1, various scales, Washington, DC.

US EPA (US Environmental Protection Agency). (2009a). National lakes assessment: A collaborative survey of the nation's lakes. EPA 841-R-09001, Washington, DC: U.S. Environmental Protection Agency, Office of Water and Office of Research and Development.

US EPA (US Environmental Protection Agency). (2009b). Columbia River basin: State of the river report for toxics January 2009. Retrieved from http://www.epa.gov/columbiariver/pdf/columbia_state_of_the_river_report_ jan2009.pdf

USGS (US Geological Survey). (2004). National hydrography dataset [Data]. Retrieved from http://nhd.usgs.gov/

USGS (US Geological Survey). (2011). Soils data for the conterminous United States derived from the NRCS State Soil Geographic (STATSGO) data base. Retrieved from http://water.usgs.gov/GIS/metadata/usgswrd/XML/ ussoils.xml

USGS (US Geological Survey). (2012a). US Land cover. Retrieved from The USGS Land Cover Institute's website: http://landcover.usgs.gov/ uslandcover.php

USGS (US Geological Survey). (2012b). Water use in the United States. Retrieved from http://water.usgs.gov/watuse/

Van Dolah, F. M. (2000). Marine algal toxins: Origins, health effects, and their increased occurrence. Environmental Health Perspectives, 108, 133-141.

Van Dolah, F. M., Roelke, D., \& Greene, R. M. (2001). Health and ecological impacts of harmful algal blooms: Risk assessment needs. Human and Ecological Risk Assessment, 7, 1329-1345.

Vörösmarty, C. J., Green, P., Salisbury, J., \& Lammers, R. (2000). Global water resources: Vulnerability from climate change and population growth. Science, 289, 284-288.

Vörösmarty, C. J., Mcintyre, P. B., Gessner, M. O., Dudgeon, D., Prusevich, A., Green, P., ... Davies, P. M. (2010). Global threats to human water security and river biodiversity. Nature, $467,555-561$.

WA DOE (Washington State Department of Ecology). (2011). Columbia River basin: Long-term water supply and demand forecast: 2011 legislative report. Yakima, WA. Retrieved from http://www.ecy.wa.gov/programs/wr/ cwp/forecast/reports.html

WA DOE (Washington State Department of Ecology). (2012). Columbia River facts and maps. Olympia, WA. Retrieved from http://www.ecy.wa. gov/programs/wr/cwp/cwpfactmap.html

Wieczorek, M. E., \& Lamotte, A. (2011). Attributes for MRB_E2RF1 catchments by major river basins in the conterminous United States (US Geological Survey Digital Data Series DS-491). Retrieved from http:// water.usgs.gov/nawqa/modeling/rflattributes.html

Wise, D. R., \& Johnson, H. M. (2011). Surface-water nutrient conditions and sources in the United States Pacific Northwest. Journal of the American Water Resources Association, 47, 1110-1135. 